DCN 92-218-044-20

$\mathrm{DOE} / \mathrm{MC} / 22118--3274$

DE93 009649

\title{
FIELD STUDY OF DISPOSED WASTES FROM ADVANCED COAL PROCESSES
}

\author{
DOE Quarterly Technical
}

Progress Report

April to June 1992

\author{
Prepared by: \\ Radian Corporation \\ 8501 Mo-Pac Boulevard \\ P.O. Box 201088 \\ Austin, Texas 78720-1088 \\ Prepared for: \\ Jerry L. Harness \\ Department of Energy \\ Morgantown Energy Technology Center \\ 3610 Collins Ferry Road \\ P.O. Box 880 \\ Morgantown, West Virginia 26505
}

Distribution:

Report Receipt (Mail Stop F07), DOE/METC (3)

Ray Butler, EERC

Andrew Covar $/ 4$

Larry Holcombe $/ 4$

Andy Weinberg/4

Tom Boyd, EPRI

Jerry Walker, Colorado Ute

Wayne Bahr IL/ENR

\section{MASTER}

DISTRIBUTION OF THIS DOCUMENT IS UNLIMATED

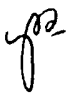


TABLE OF CONTENTS

Page

$1.0 \quad$ OBJECTIVES $\ldots \ldots \ldots \ldots \ldots \ldots \ldots \ldots \ldots \ldots \ldots \ldots$

$2.0 \quad$ SUMMARY OF PREVIOUS WORK $\ldots \ldots \ldots \ldots \ldots \ldots$

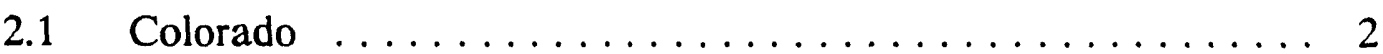

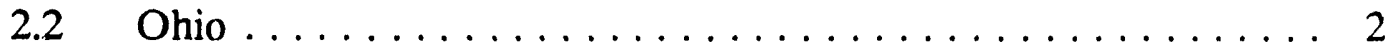

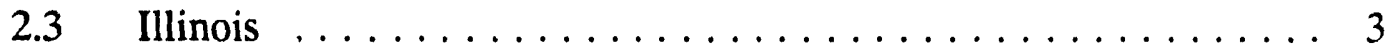

3.0 OBJECTIVES FOR THE CURRENT REPORTING PERIOD . . . . 4

$4.0 \quad$ ACTIVITIES FOR THE REPORTING PERIOD $\ldots \ldots \ldots \ldots \ldots$

$4.1 \quad$ Colorado Ute Site $\ldots \ldots \ldots \ldots \ldots \ldots \ldots \ldots \ldots$

4.2 Ohio Site ....................... 6

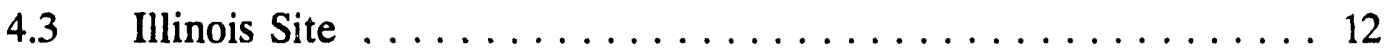

$5.0 \quad$ ACTIVITIES PLANNED FOR THE NEXT QUARTER $\ldots \ldots \ldots$

APPENDIX A: TECHNICAL NOTE

\section{DISCLAIMER}

This report was prepared as an account of work sponsored by an agency of the United States Government. Neither the United States Government nor any agency thereof, nor any of their employees, makes any warranty, express or implied, or assumes any legal liability or responsibility for the accuracy, completeness, or usefulness of any information, apparatus, product, or process disclosed, or represents that its use would not infringe privately owned rights. Reference herein to any specific commercial product, process, or service by trade name, trademark, manufacturer, or otherwise does not necessarily constitute or imply its endorsement, recommendation, or favoring by the United States Government or any agency thereof. The views and opinions of authors expressed herein do not necessarily state or reflect those of the Inited States Government or any agency thereof. 


\section{LIST OF FIGURES}

Page

Groundwater and Porewater Monitoring Locations at the Ohio Test Site 7 Major Element Concentrations in Groundwater Samples from Wells Downgradient of the Ohio North Cell for All Sampling Events . . . . . 8

Major Element Concentrations in Groundwater Samples from Wells Downgradient of the Ohio South Cell for All Sampling Events ...... 9

Major Element Concentrations in Groundwater Samples from Wells Upgradient of the Ohio Test Cells for All Sampling Events ....... 10

Major Element Concentrations from Lysimeters at Different Depths in the Ohio South Cell for All Sampling Events ............ 11

Groundwater and Porewater Monitoring Locations at the Illinois Test Sitd3

Major Element Concentrations in Groundwater Samples from Wells Upgradient and Downgradient of the Illinois Test Cell for All Sampling Events ........................... 14

Trends in Concentrations of Major Elements with Depth in ASTM Deionized Water Leachates from Illinois 1992 Annual Core Samples . . 15

Average Major Element Concentrations in ASTM Leachate of Ash from the Illinois Test Cell $\ldots \ldots \ldots \ldots \ldots \ldots \ldots \ldots \ldots$ 


\section{LIST OF TABLES}

Page

Chemical Characteristics of Liquid from Ohio, Event II . . . . . . . . 19

Chemical Characteristics of Liquid from Illinois, Event $4 \ldots \ldots \ldots 27$

3

Chemical Characteristics of Ash from Illinois, Event $4 \ldots \ldots \ldots 35$ 
The Department of Energy/Morgantown Energy Technology Center (DOE/METC) has initiated research on the disposal of solid wastes frorn advanced coal processes. The objective of this research is to develop information to be used by private industry and government agencies for planning waste disposal practices associated with advanced coal processes. To accomplish this objective, DOE has contracted Radian Corporation and the North Dakota Energy \& Environmental Research Center (EERC) to design, $c$. uct, and monitor a limited number of field disposal tests with advanced coal process wastes. These field tests will be monitored over a three year period with the emphasis on collecting data on the field disposal of these wastes.

There has been considerable research on the characteristics and laboratory leaching behavior of coal wastes -- a lesser amount on wastes from advanced coal processes. However, very little information exists on the field disposal behavior of these wastes. Information on field disposal behavior is needed (a) as input to predictive models being developed, b) as input to the development of rule of thumb design guidelines for the disposal of these wastes, and c) as evidence of the behavior of these wastes in the natural environment.

\section{SUMMARY OF PREVIOUS WORK}

This study is organized into four major Tasks. Tasks 1 and 2 were devoted to planing the Task 3 field study. Task 4 uses the results of the field testing to produce an Engineering Design Manual for the utilities and industrial users who manage wastes from advanced coal combustion technologies.

Task 1 identified and rated test design options. A Test Design Manual was prepared and submitted to METC in 1988. Specific test procedures suitable for each design option were identified under Task 2 . These test methods were documented in a 
Test Procedures Manual, submitted to METC in 1988. Also under Task 2, test sites were selected and site access was negotiated. Sites in Illinois and North Dakota were delayed at this stage, and the North Dakota site was dropped from consideration. Task 2 was completed and Final Test Plans were submitted to METC for three sites in 1988.

Task 3 progress for each of the test sites is summarized below:

\section{$2.1 \quad$ Colorado}

The test cell was constructed in June, 1989 with CFBC ash from a low sulfur western coal. The ash has low lime and sulfate content. Core samples were collected in June and December 1989, in March, June and December of 1990, in June 1991, and most recently in June 1992. No groundwater or porewater samples have been recovered. At this time the three year monitoring period at the Coiorado site is completed; further field monitoring at this site is under discussion with the DOE and other parties.

The strength of core samples from the Colorado site is low to moderate ( $200 \mathrm{psi}$ to $900 \mathrm{psi}$ ), with permeabilities of $2 \times 10^{-3}$ to $3 \times 10^{-4}$. Laboratory leachates show moderate concentrations of calcium, sulfate, and other common ions. Trace element concentrations in test leachates are low compared to regulatory limits. No leachate has been generated from the test cell at this site.

\section{2}

\section{$\underline{\text { Ohio }}$}

Two test cells were constructed, in February and April of 1989, using LIMB ash from an Ohio coal with $2.4 \%$ sulfur. The ash has a high lime and sulfate content. Test case 1 (north cell) was constructed with $25 \%$ moisture; test case 2 was constructed with $38 \%$ moisture to optimize compaction. The wastes expanded, heaved, and fractured during the first year, particularly in the south cell. Mineralogical changes 
in the wastes with hydration and weathering are the primary cause. Core strength is moderate to low (2000 psi to $<100 \mathrm{psi}$ ) and highly variable because of fracturing. Field measurements of permeability vary from $3 \times 10^{-3}$ to $5 \times 10^{-5} \mathrm{~cm} / \mathrm{sec}$. Permeabilities are lowest in the north cell.

Large amounts of water were bound in the wastes in the first year as the waste saturated and hydrated. Starting in the second year, leachate appears to have migrated out of the south cell into downgradient wells. The leachate at the bottom of the test cell contains up to several thousand $\mathrm{mg} / \mathrm{L}$ of sulfate, chloride, potassium, and sodium, with somewhat lower concentrations of calcium and silicon. Trace metal concentrations are generally low compared to regulatory limits, but a few samples contain arsenic at concentrations up to $0.35 \mathrm{mg} / \mathrm{L}$.

Core samples were first collected in June, 1989, and quarterly and annual core sampling events have taken place according to schedule since that time. Water samples have been collected on a quarterly basis since October, 1989. Final core sampling for the three year monitoring period is scheduled for August, 1992. Further monitoring, on a limited basis, is under discussion with the DOE and Ohio Edison.

\section{3}

\section{Illinois}

The first Illinois test cell was completed in April, 1991, with bubbling FBC ash from a Illinois coal with $3.1 \%$ sulfur. A large excess of limestone is used in the combustor; the ash is high in lime rela sive to most FBC wastes, containing up to $30 \% \mathrm{CaO}$. The ash also contains abundant sulfate, but has relatively low concentrations of coal ash compared to other wastes included in this study. The two test cells planned for the second Illinois test case will evaluate the effects of added coal ash on cementitious reactions in the waste. Laboratory studies to define the optimum mix of FBC waste and coal fly ash are completed, and cell construction is planned for August, 1992. 
The initial cell was instrumented and sampled in June 1991. Water samples and additional cores were collected in August and November, 1991, and February and May, 1992. No expansion has been noted at the site. The wastes are solidified with unconfined compressive strength between approximately 150 and $550 \mathrm{psi}$, although some fracture zones may be present in the waste and may reduce overall strength. The permeability measured on cores recovered from the test cell ranges from $1 \times 10^{-6}$ to $2 \times 10^{-4}$; field permeability measurements range from a high of $3 \times 10^{-3}$ near the surface to a low of $2 \times 10^{-5}$ at depth in the test cell.

\section{OBJECTIVES FOR THE CURRENT REPORTING PERIOD}

The specific objectives for the reporting period of April, 1992 to July, 1992 were as follows:

- $\quad$ Collect third annual core samples at the Colorado site in June, 1992. Make final field measurements on site to complete the three year monitoring period;

- Prepare a Technical Note on the surface water runoff from the Colorado Ute test cell;

- Collect quarterly samples at the Ohio site in May, 1992. Measure permeability and moisture content, and collect water samples from the wells and lysimeters;

- Collect the first annual cores and fourth quarterly water samples from the first Illinois test case in May, 1992. Make field measurements and collect data from the data logger;

- Analyze chemistry of all core and water samples collected;

- Complete preliminary laboratory testing for the second Illinois test case;

- Continue production of a video presentation on the project; 
- Load all EERC data on the second annual cores from Colorado and Ohio and the first two sets of quarterly samples from Illinois into the project database;

- Draft a proposal to DOE/METC for continued field monitoring at the Ohio site beyond the present 3 year period;

- Complete Preliminary Assessment reports on the Ohio and Colorado sites for the DOE, pending receipt of DOE comments on the initial drafts; and

- $\quad$ Complete a memorandum detailing costs to complete the initial three years of monitoring at all sites for the DOE.

ACTIVITIES FOR THE REPORTING PERIOD

4.1

\section{Colorado Ute Site}

Third annual core samples were collected from the Colorado site June 17 and 18, 1992. The samples were distributed to the EERC and Radian laboratories for analysis. No results are available at this time.

A brief Technical Note discussing the surface runoff from the Colorado Ute test cell was prepared for the DOE. Calculations showed that runoff should constitute only about $0.2 \%$ of the water budget for the test site, with the vast majority of the rainwater falling at the site being evaporated. The chemistry of the one runoff sample collected at the site had a low dissolved solids content and a moderately alkaline $\mathrm{pH}$. Data from this test cell indicate that there is a low possibility for appreciable impacts on surface water quality from runoff from FBC wastes similar to the Colorado Ute FBC material. The Technical Note is attached to this report as Appendix A. 
Quarterly water samples were collected from the Ohio site in May, 1992. Analytical results for these samples are presented in Table 1. A diagram of the Ohio site is shown in Figure 1. The upgradier.t and downgradient groundwater compositions measured to date are shown in Figures 2 through 4. In each figure, separate graphs are shown, each providing data for groundwater from a different depth interval. Figures 2 through 4 illustrate the strong dependence of the groundwater chemistry at the Ohio site on the depth of sampling.

As previously discussed, the chloride concentration in groundwater samples from the shallow well downgradient of the south cell (OHMW-06) appear to have been impacted by leachate from the test cell. Chloride concentrations have increased in OHMW-06, while the chloride concentrations in OHMW-03, completed at the same depth downgradient of the north cell, and in OHMW-08, completed at the same depth upgradient of the test cells, have remained stable. None of the other analytes in OHMW-06 show a similar pattern of increasing concentration. Statistical tests are being performed on this data to assess its significance.

Major element concentration in some of the lysimeters from the south cell are shown in Figure 5. Although all lysimeters at the site do not yield a sample every quarter, the overail trend has been towards decreasing concentration of major elements over time in both cells and at all depths. Eleventh quarter lysimeter samples were available only from OHLY-11 and OHLY-12 of the lysimeters shown in this figure. Data from these two lysimeters indicates a break in the trend towards lower major element concentrations. Major element concentrations may be stabilizing at these lower values as the waste in the tests cell become drier. 

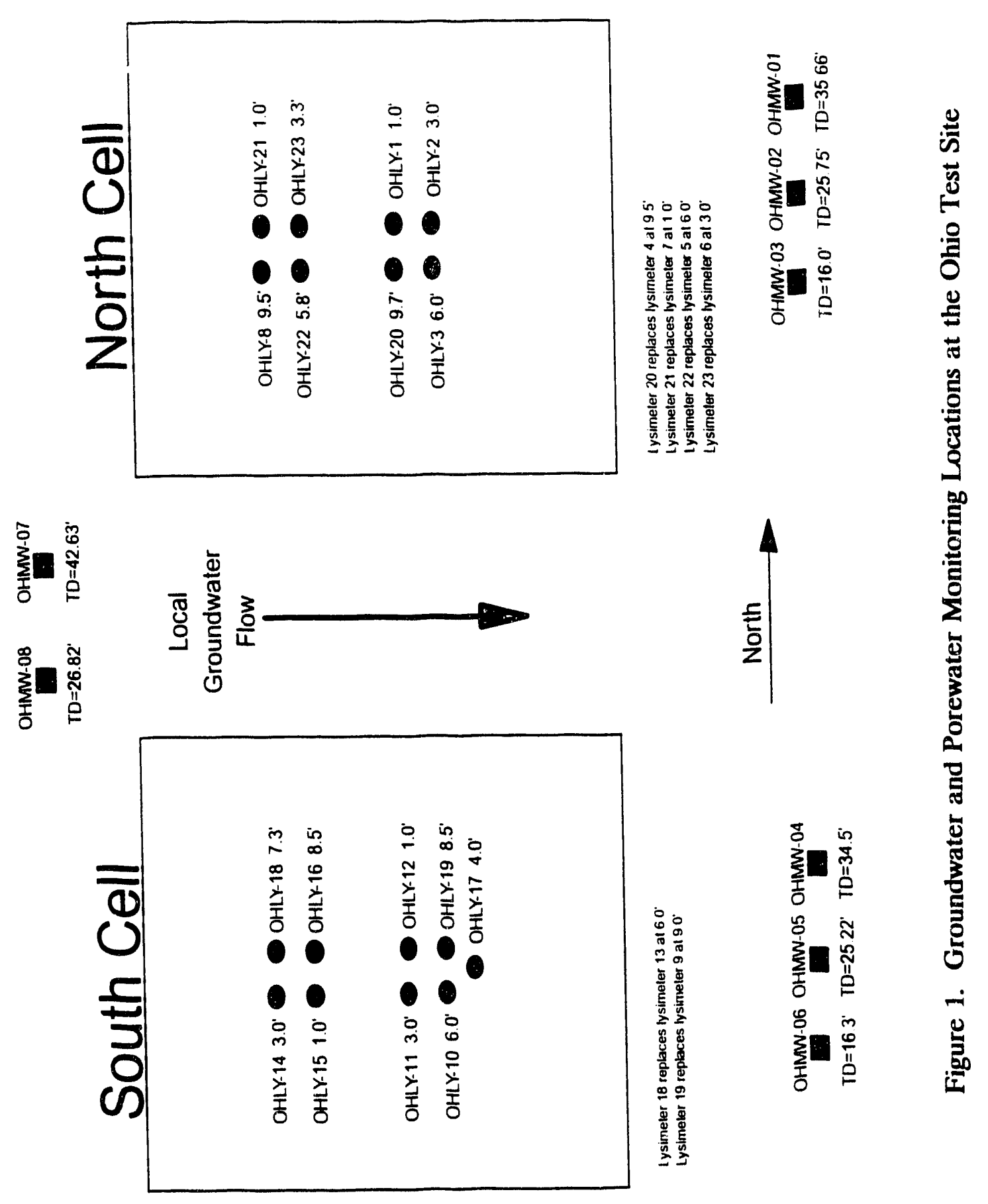


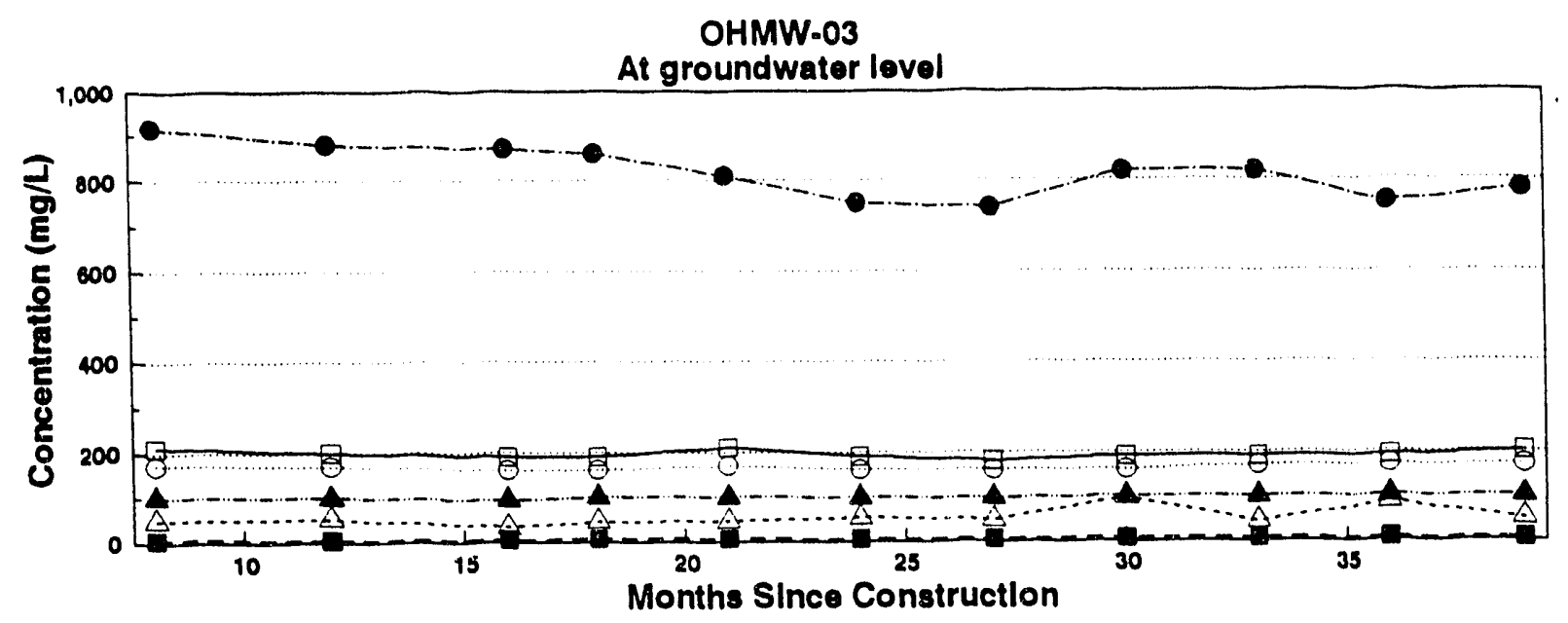

OHMW-02

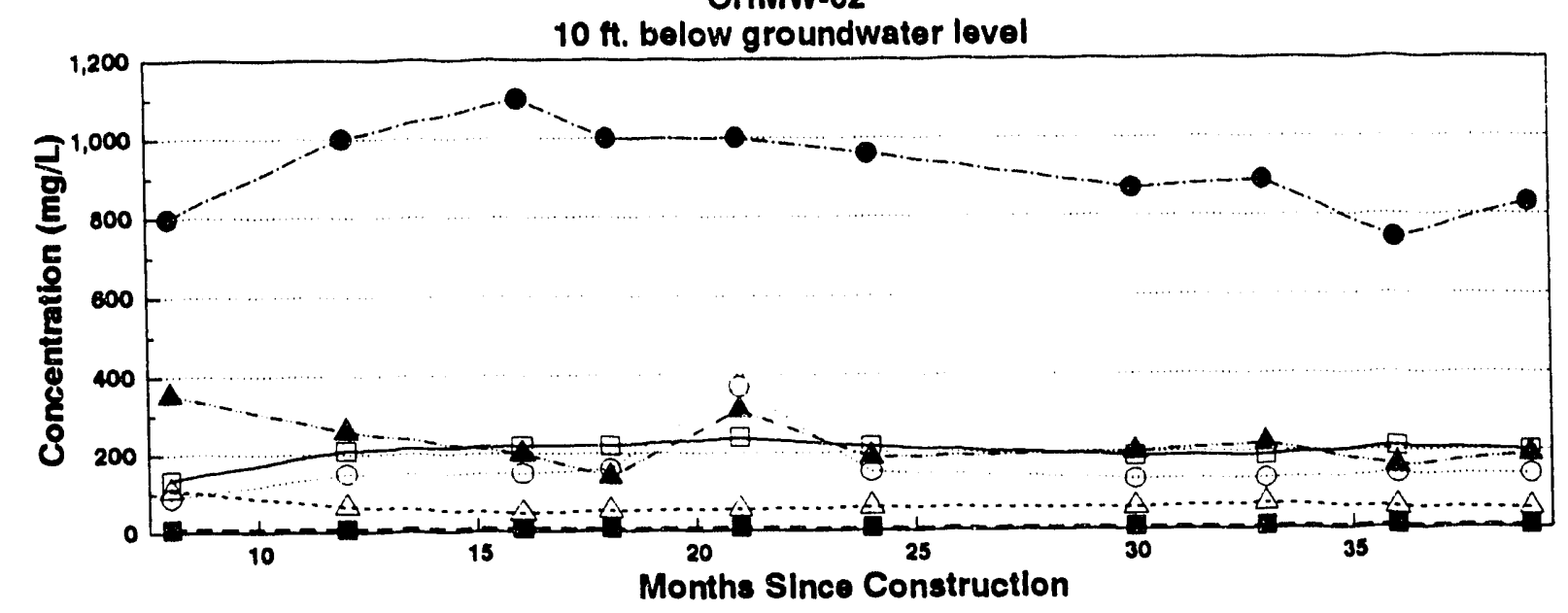

OHMW.01

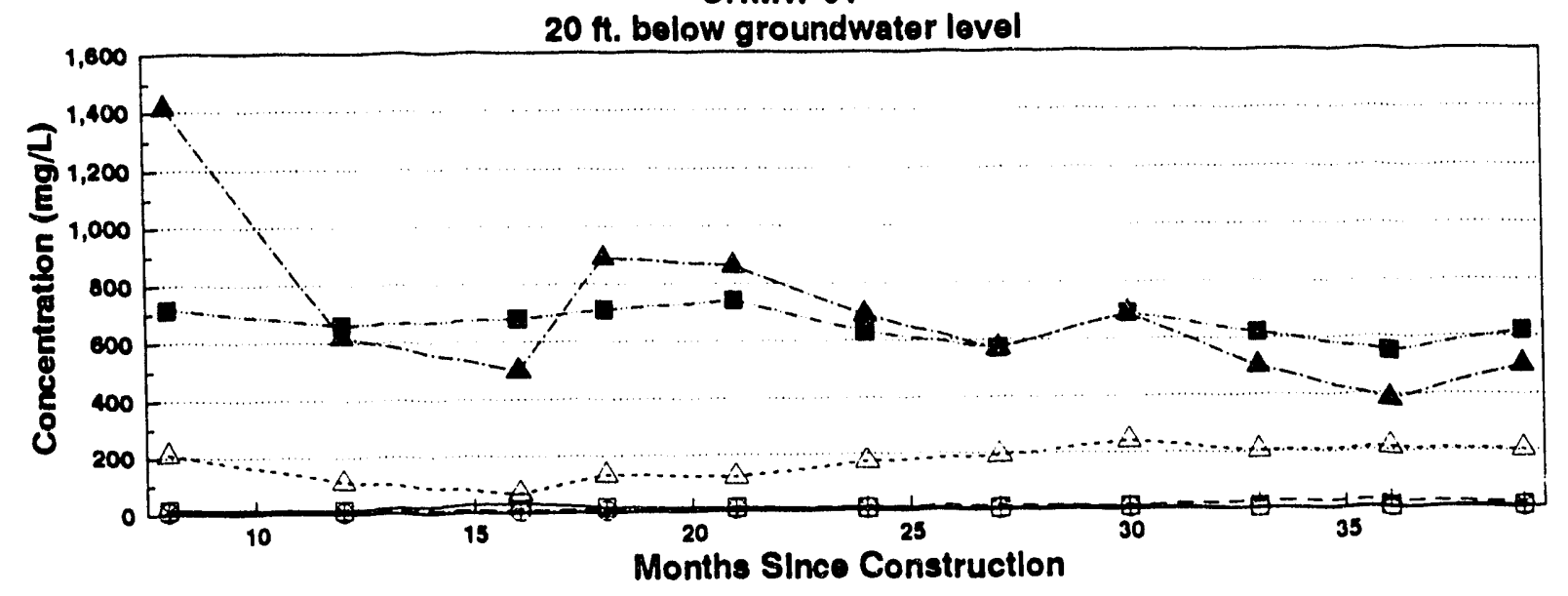

Calclum Chloride Magneslum Potasslum Sodlum Sulfate

Figure 2. Major Element Concentrations in Groundwater Samples from Wells Downgradient of Ohio North Cell for All Sampling Events 

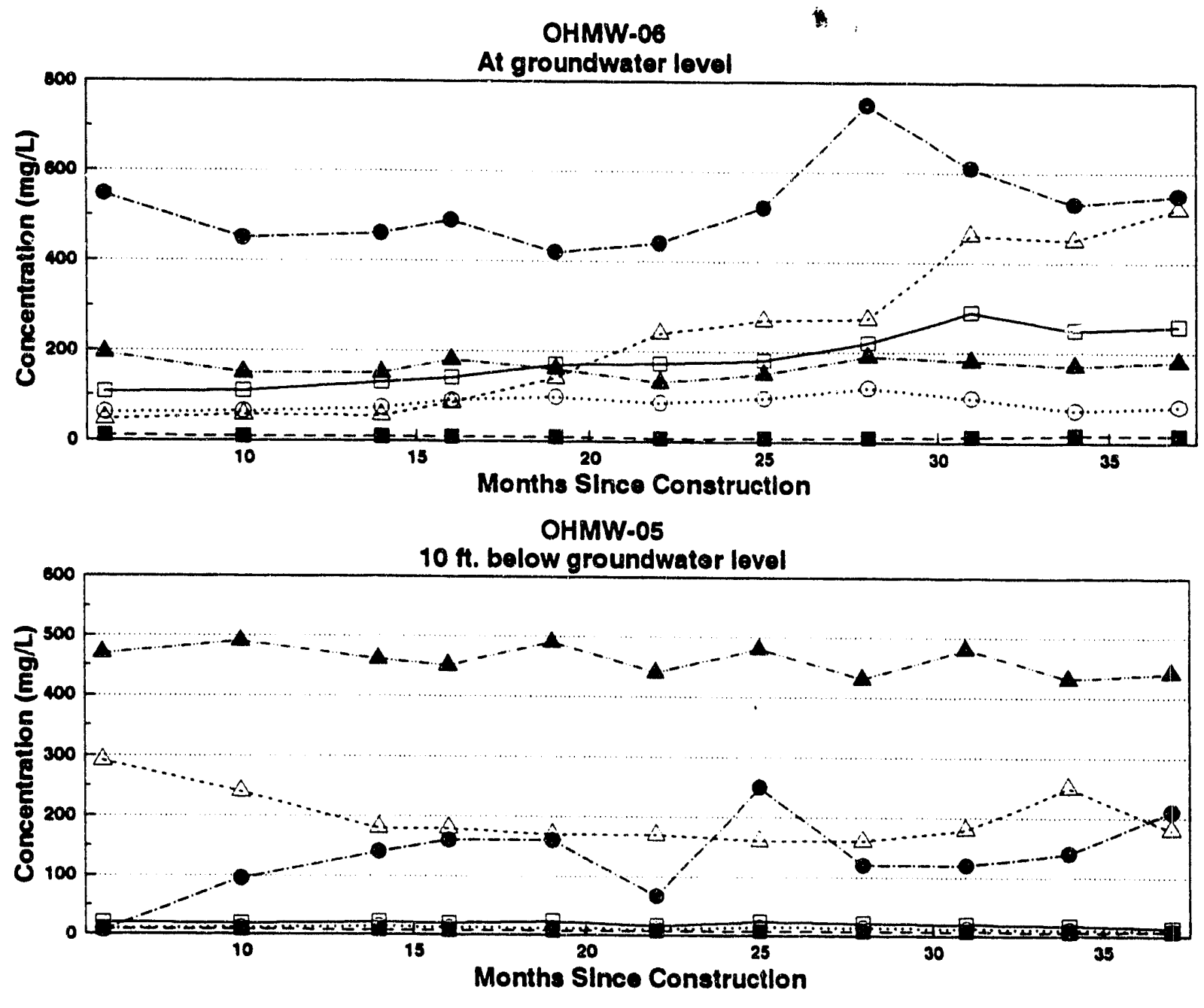

OHMW-04

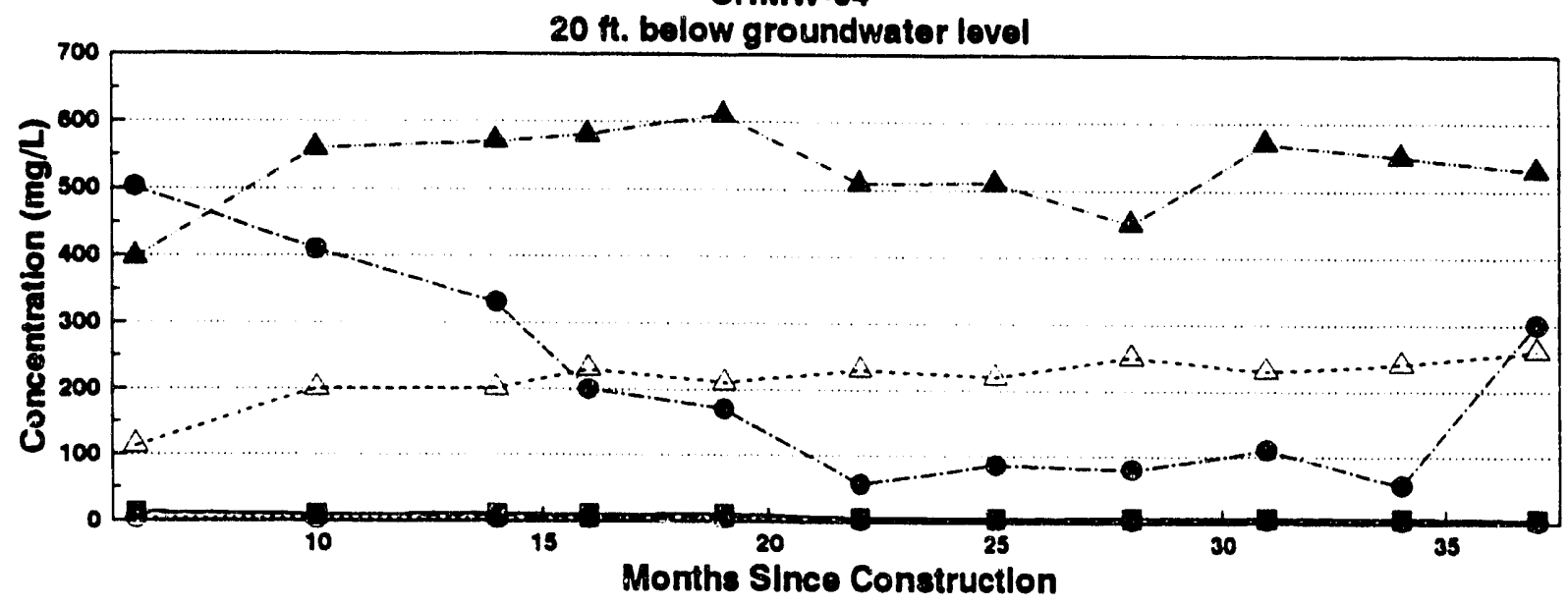

Calclum Chloride Magneslum Potassium Sodlum Sulfate

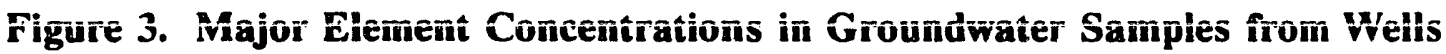
Downgradient of the Ohio South Cell for All Sampling Events 


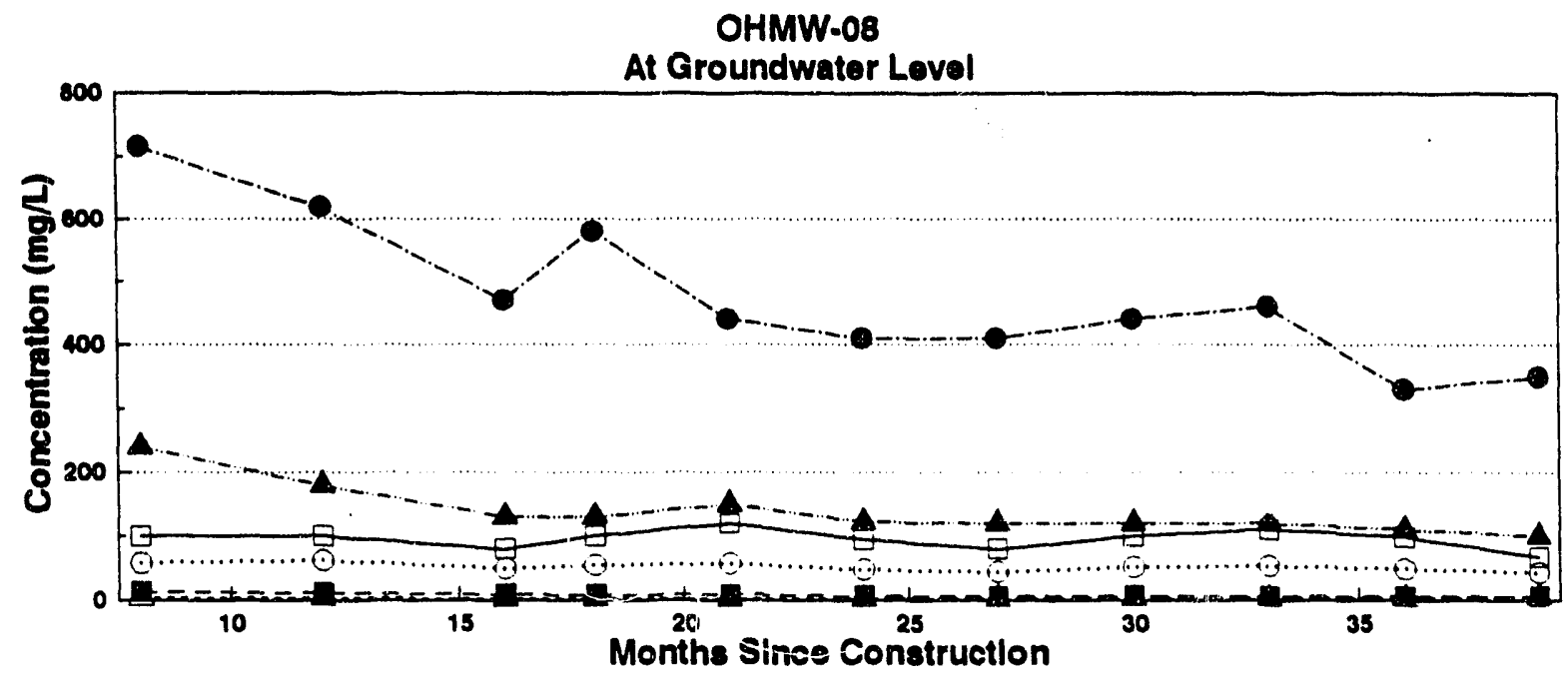

OHMW-07

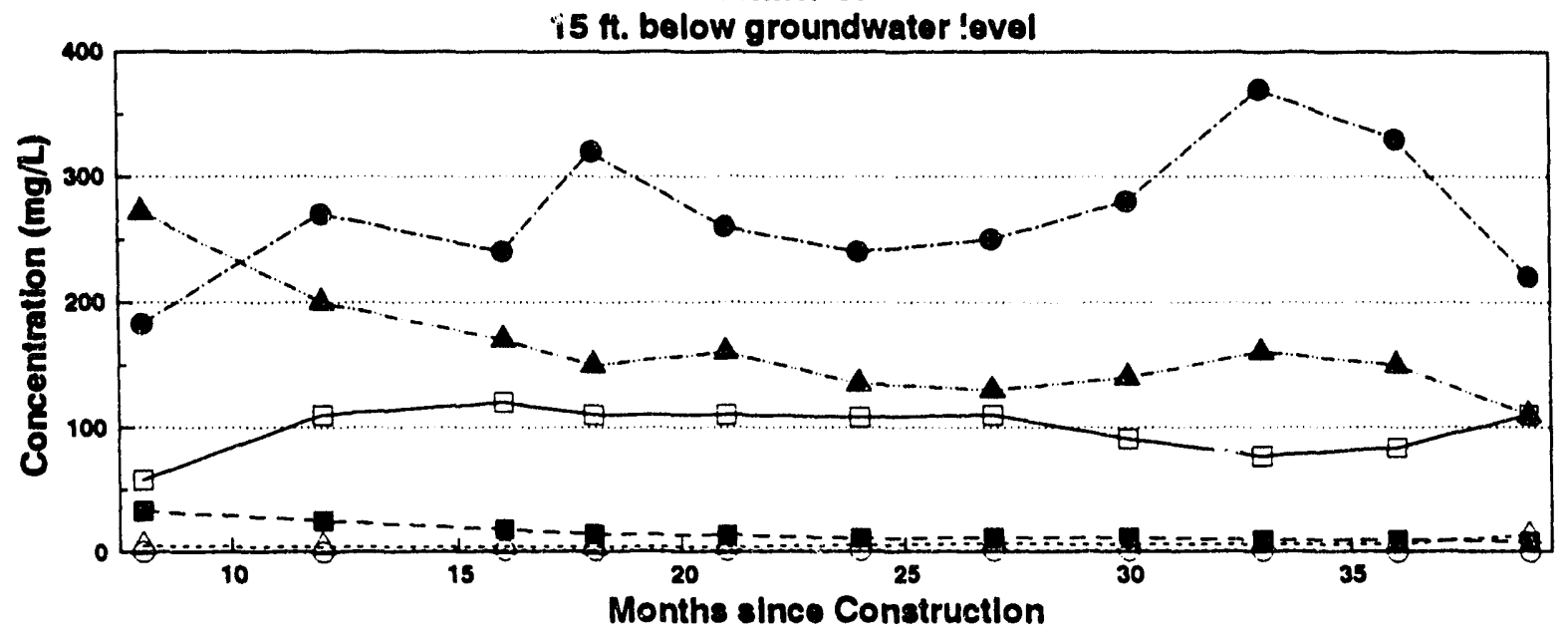

Calclum Chiorlde Magneslum Potasslum Sodlum Sulfate

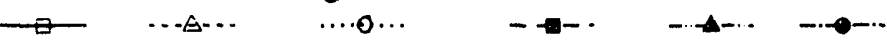

Figure 4. Major Element Concentrations in Groundwater Samples from Wells Upgradient of the Ohio Test Cells for All Sampling Events 

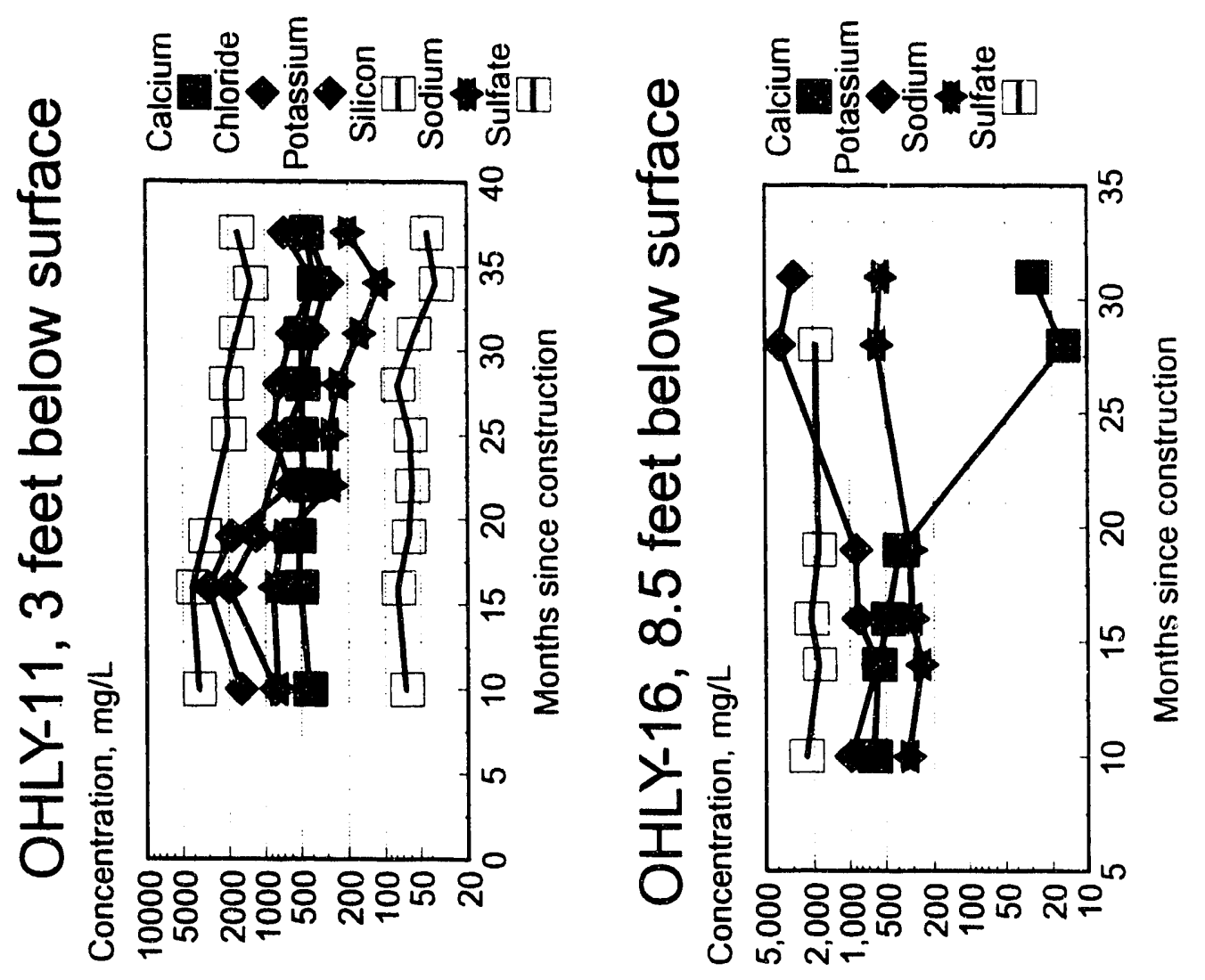

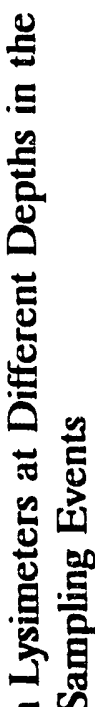
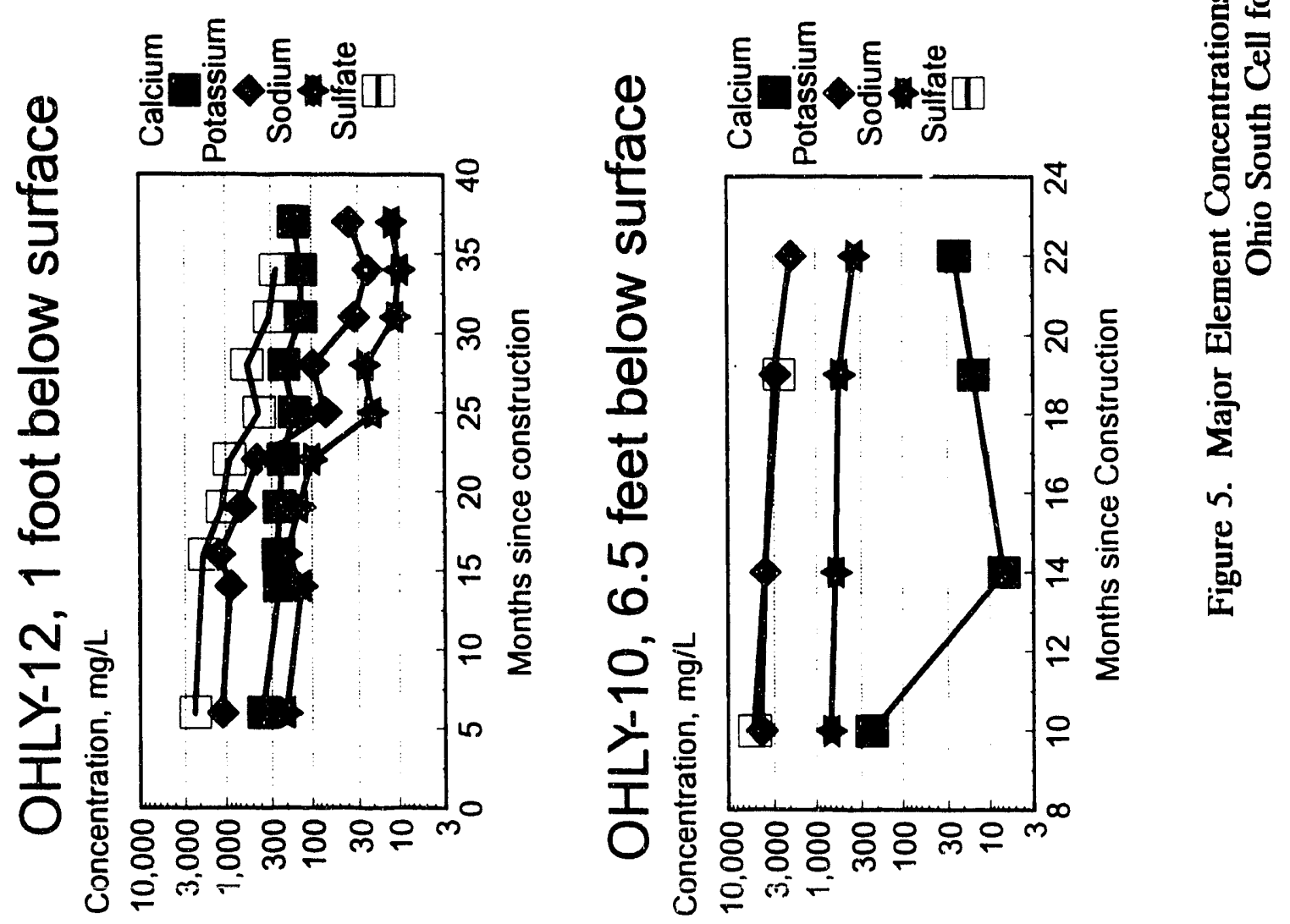
The fourth set of quarterly water samples and the first set of annual core samples was collected in May, 1992, and analyzed in June. The analytical results for water samples are shown in Table 2, and those for ASTM leachates of the ash and soil samples are presented in Table 3. A diagram of the Illinois site is shown in Figure 6.

Major element concentrations in groundwater samples from the Illinois site are illustrated in Figure 7. Downgradient wells appear to have a higher variability in major element concentrations than do the upgradient wells. No clear compositional trends can be distinguished at this time.

Most of the lysimeters from the Illinois site remain dry. Water has been recovered from a few of the near-surface lysimeters installed in the test cell, but not enough data is available to show changes with depth or time. Sulfate, potassium, sodium, and chloride make up the major dissolved components in the porewater at this site.

The quarterly core samples have provided a more consistent. record than the lysimeters in the first year of sampling at the Illinois site. Concentrations of highly soluble species including potassium, sodium, and chloride are lower in laboratory test leachates from the shallowest samples than in leachates from samples deeper in the cell, as shown in Figure 8. This trend suggests that the most soluble elements are gradually leaching through the test cell. The depletion of soluble constituents from the upper portions of the test cell is consistent with the pattern of leaching observed in the Ohio test cells. Calcium and sulfate concentrations in the ASTM deionized water leachates of the annual core samples do not exhibit significant changes with depth; the solubility of the mineral gypsum, which is a major constituent of the hydrated waste, controls the concentrations of calcium and sulfate in solution. 


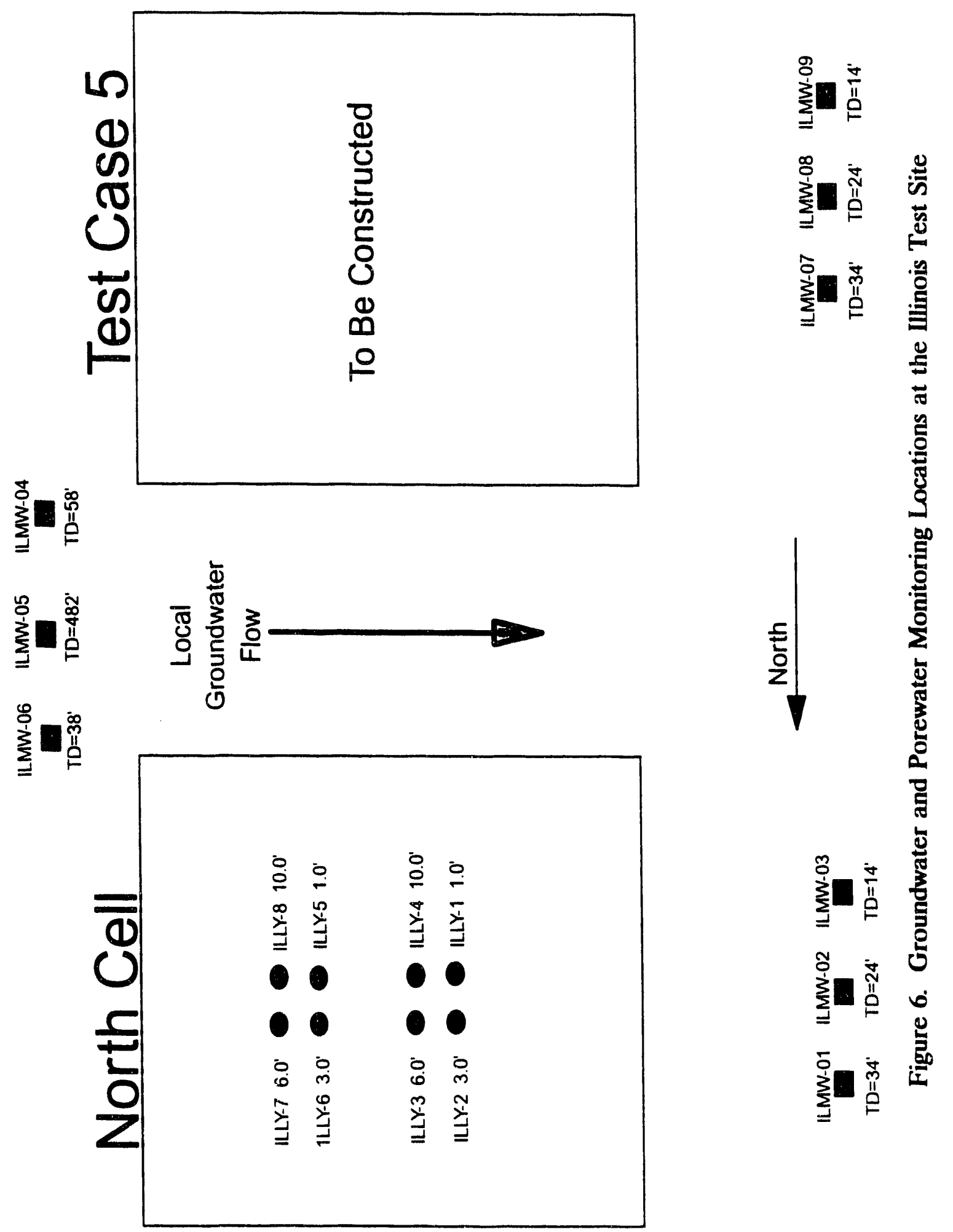




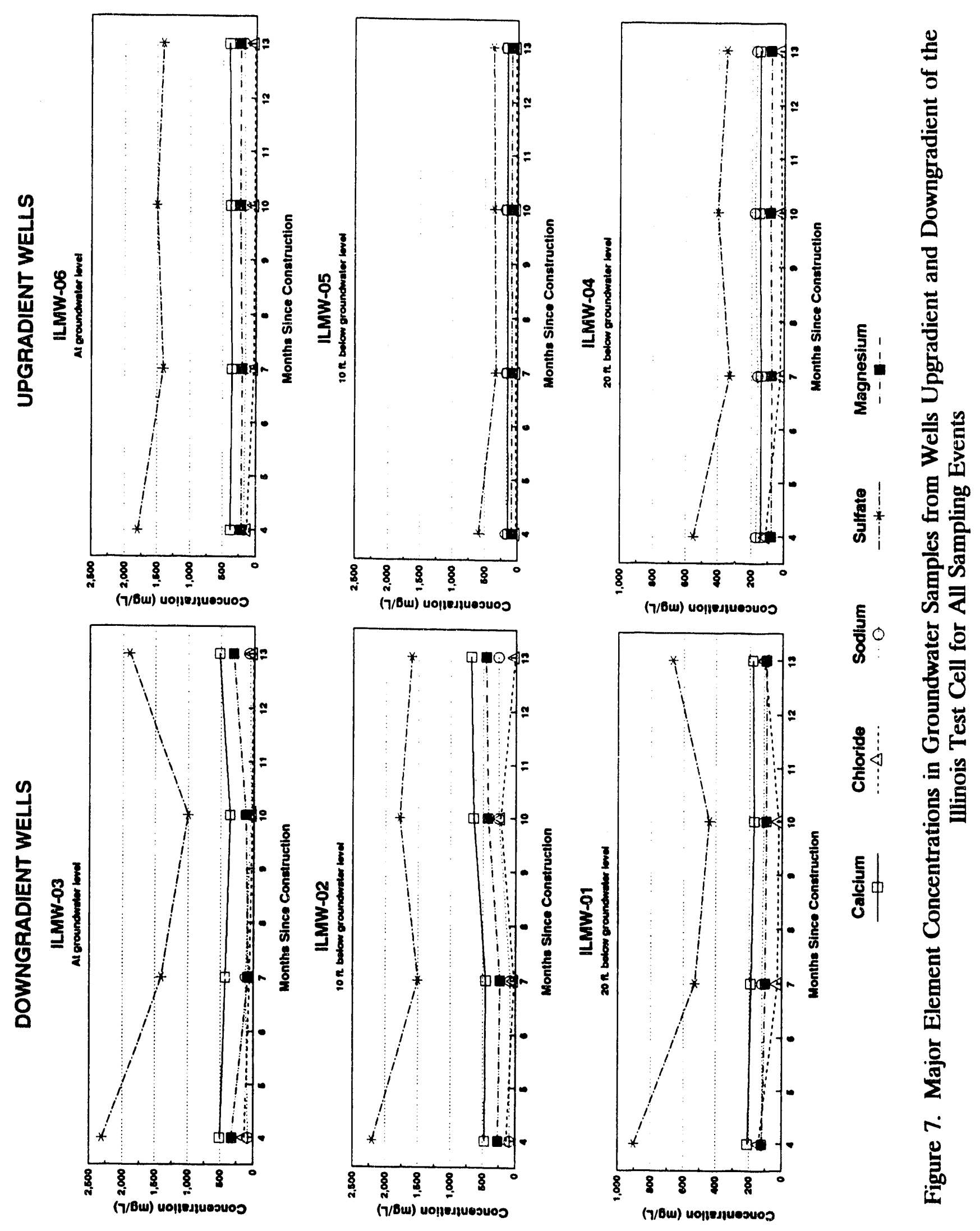


Depth, $\mathrm{ft}$

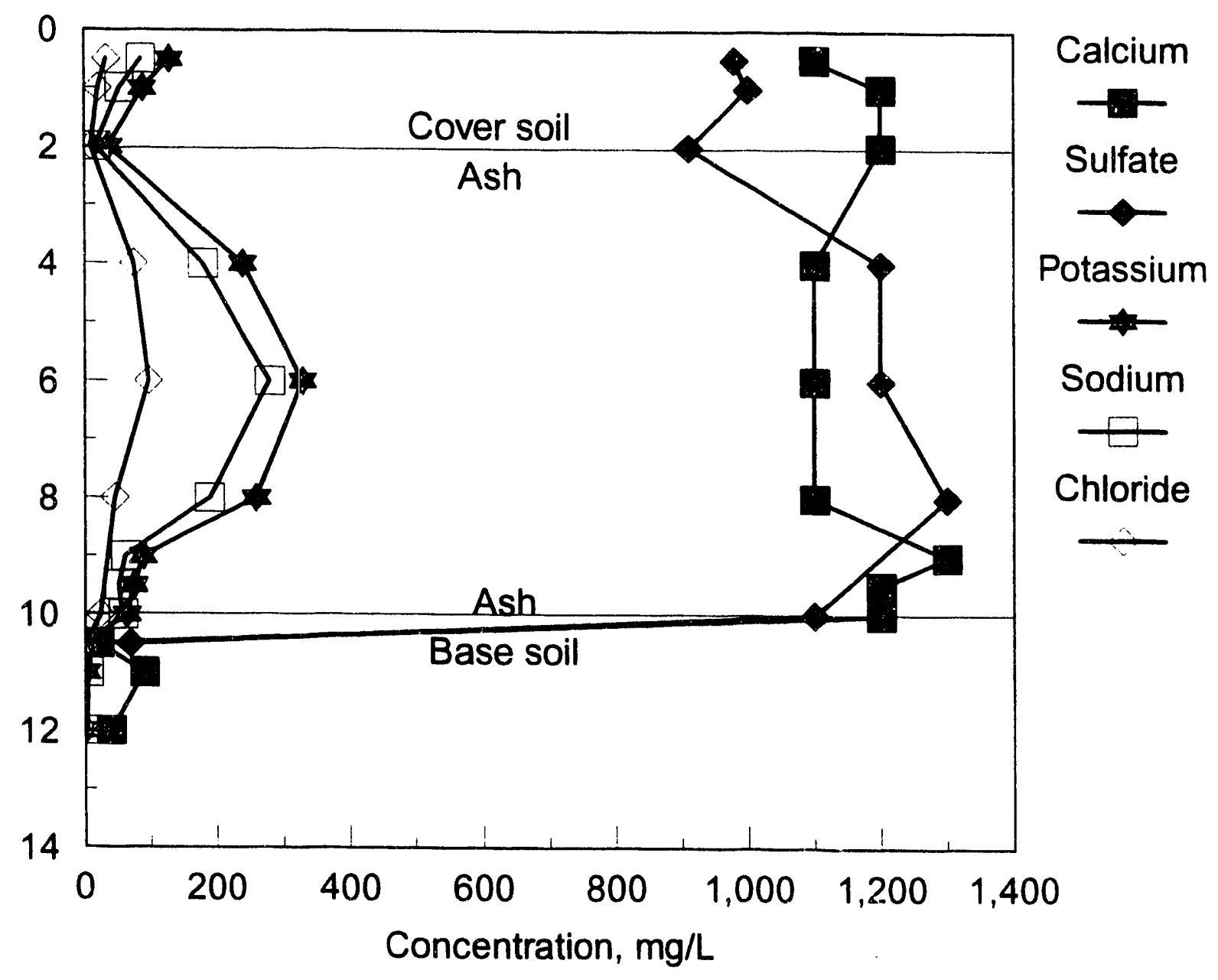

Figure 8. Trends in Concentrations of Major Elements with Depths in ASTM Deionized Water Leachates from Illinois 1992 Annual Core Samples 
Although there appears to be some mobilization of soluble materials near the waste surface, the average major element concentrations in the ASTM deionized water leachates from core samples from all depths in the waste have not changed significantly since the test cell was completed. Figure 9 shows the average concentrations of calcium, chloride, potassium, sodium, and sulfate in leachates from core samples from each field sampling event and from the initial ash. There is more soluble sodium and potassium in the material sampled from the test cell than in the initial ash, but leachable concentrations of all the major elements have remained stable since the test cell was first sampled in June 1991.

Initial laboratory testing of mixtures of the Midwest Grain FBC waste and fly ash is nearly completed. Final tests for length change during curing and for freeze/ thaw durability will be completed in July. Bench scale mixing tests of FBC/fly ash mixtures will also be carried out before the test cell construction plans are finalized.

The following activities are planned for the period of July 1992 through September 1992:

- The final sampling event at the Ohio site under the current three year scope is scheduled for August, 1992. Environmental monitoring measurements will be made, and water and core samples will be collected;

- Chemical analysis of core and water samples will continue;

- The fifth quarterly water samples from the first Illinois test case will be collected in August; other field measurements will also be made at that time;

- Construction of the second Illinois test case will begin;

- Radian will continue production of a short video presentation on the advanced coal wastes test program; 


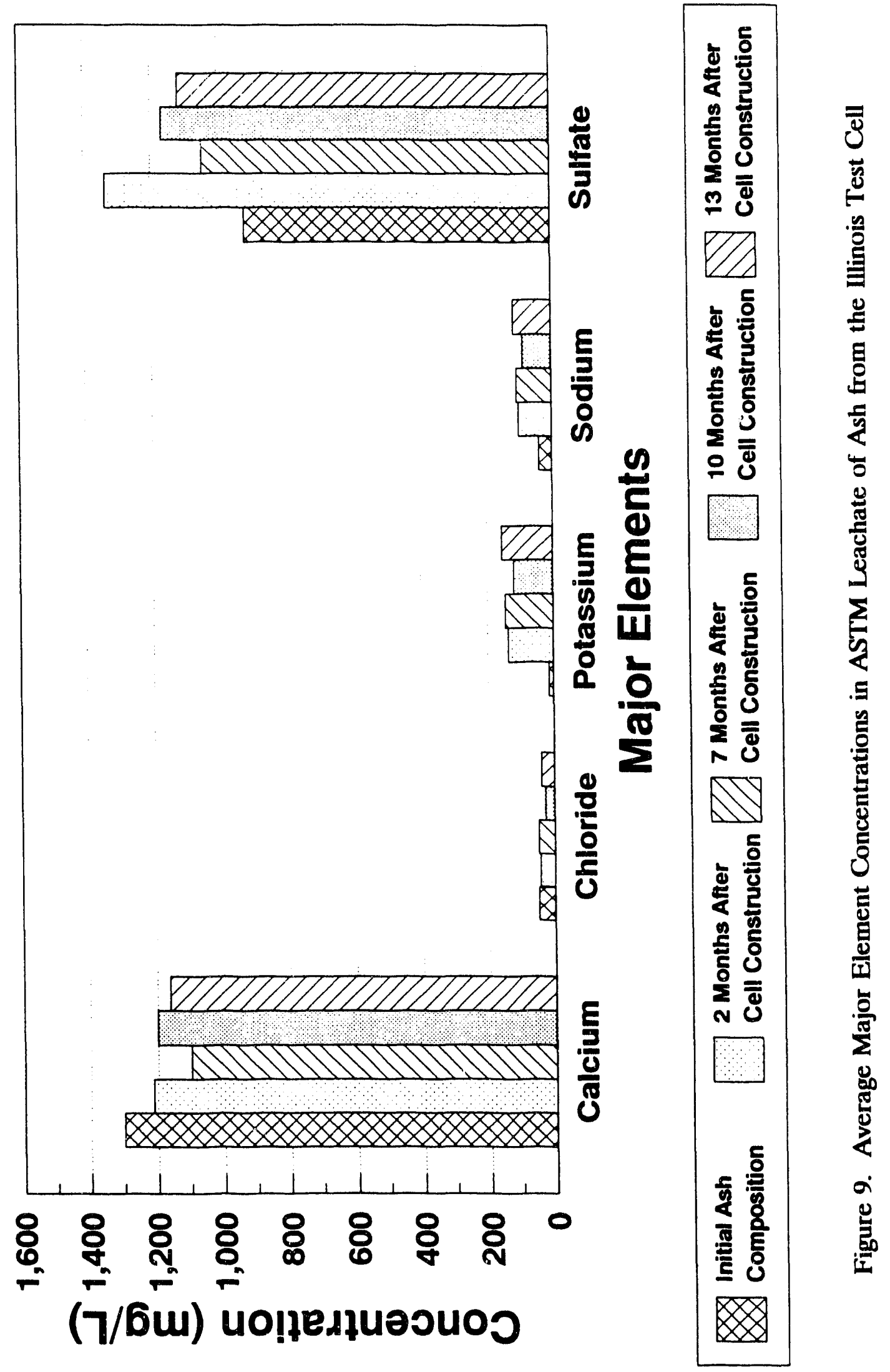


- $\quad$ EERC data will continue to be loaded onto the project database and reported as available. Complete results for the Colorado and Ohio sites will be provided with the final site reports, and

- $\quad$ Preliminary Case Reports on the Colorado and Ohio test cases will be finalized, and costs to complete the three year initial scope of testing at all sites will be submitted to METC. 


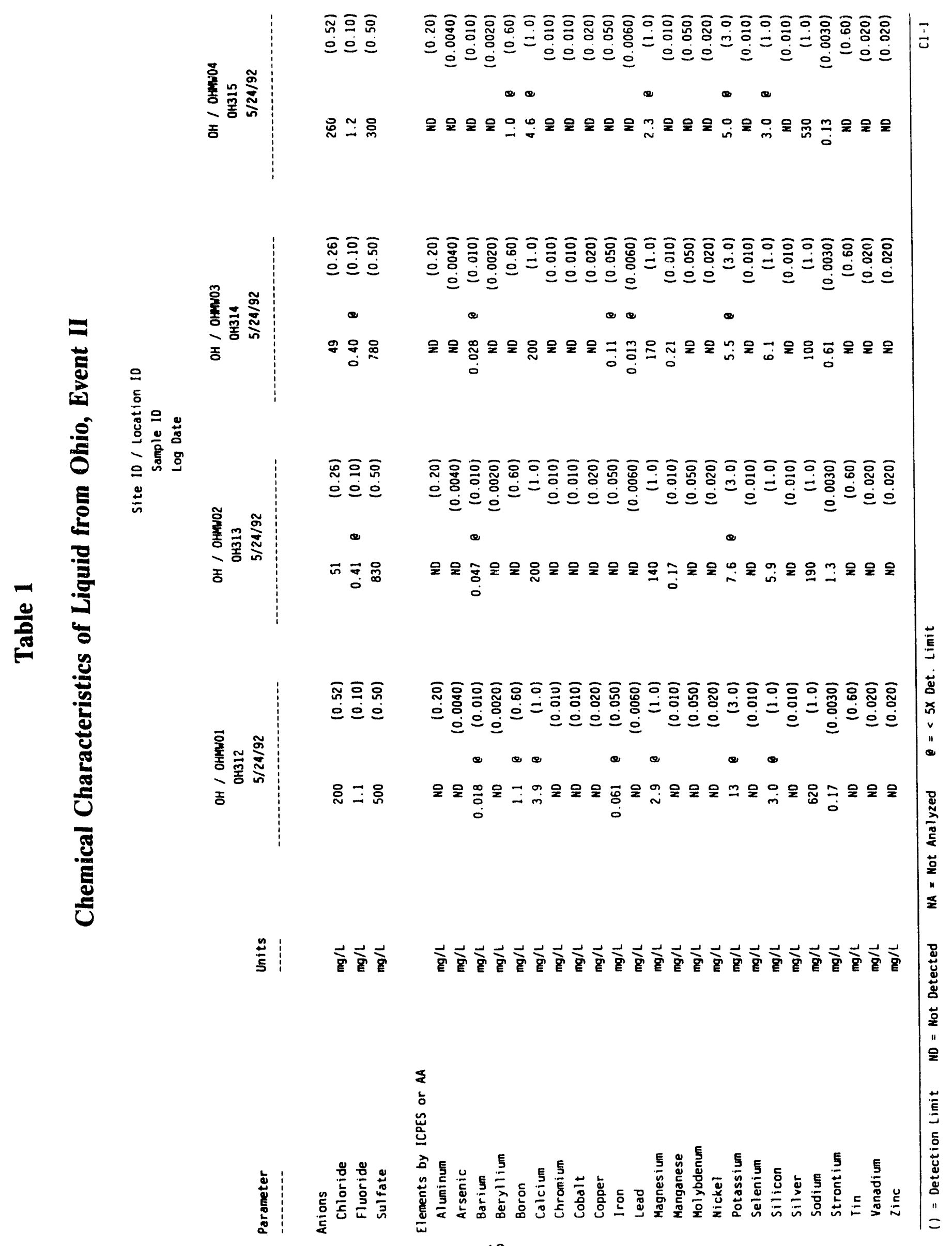




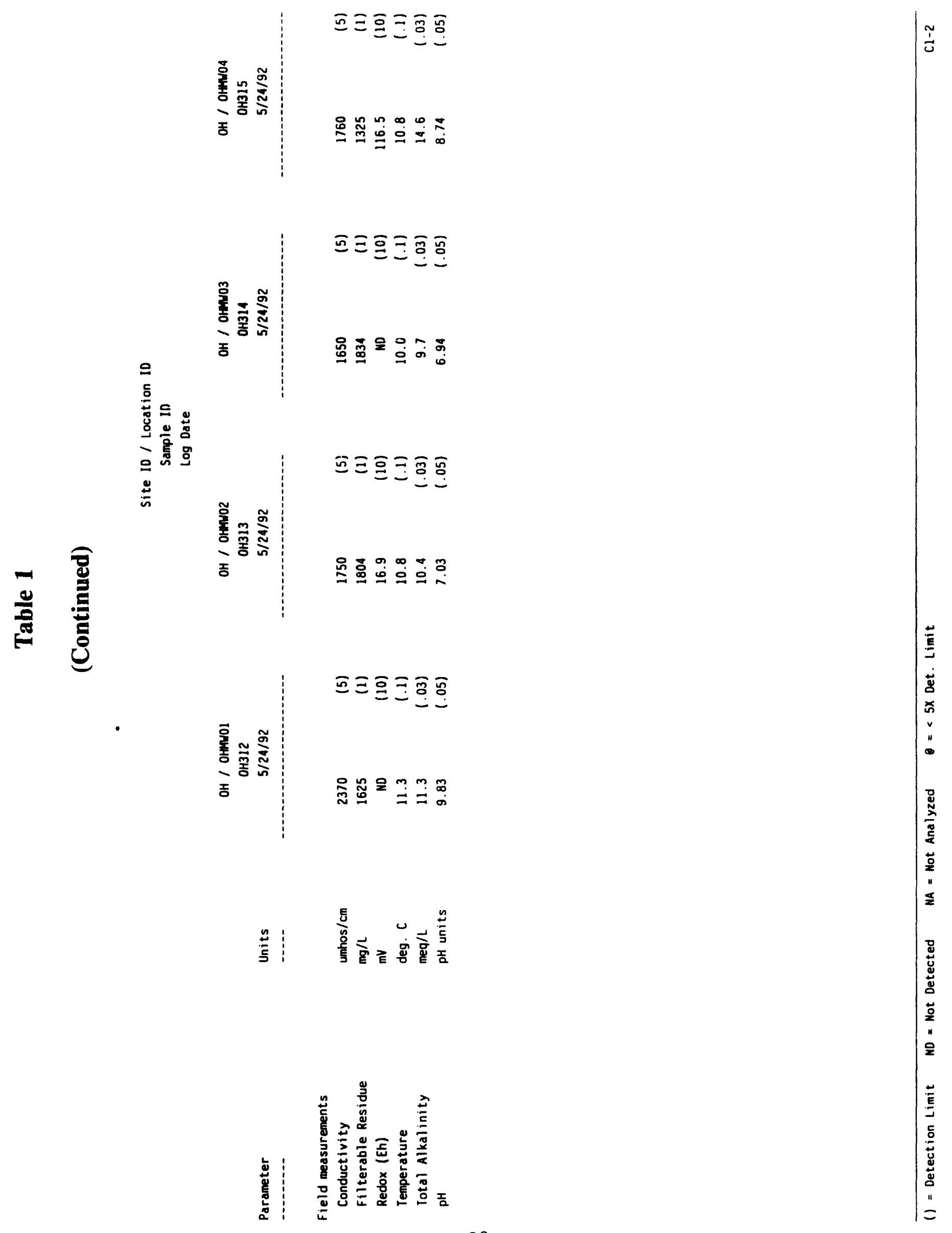




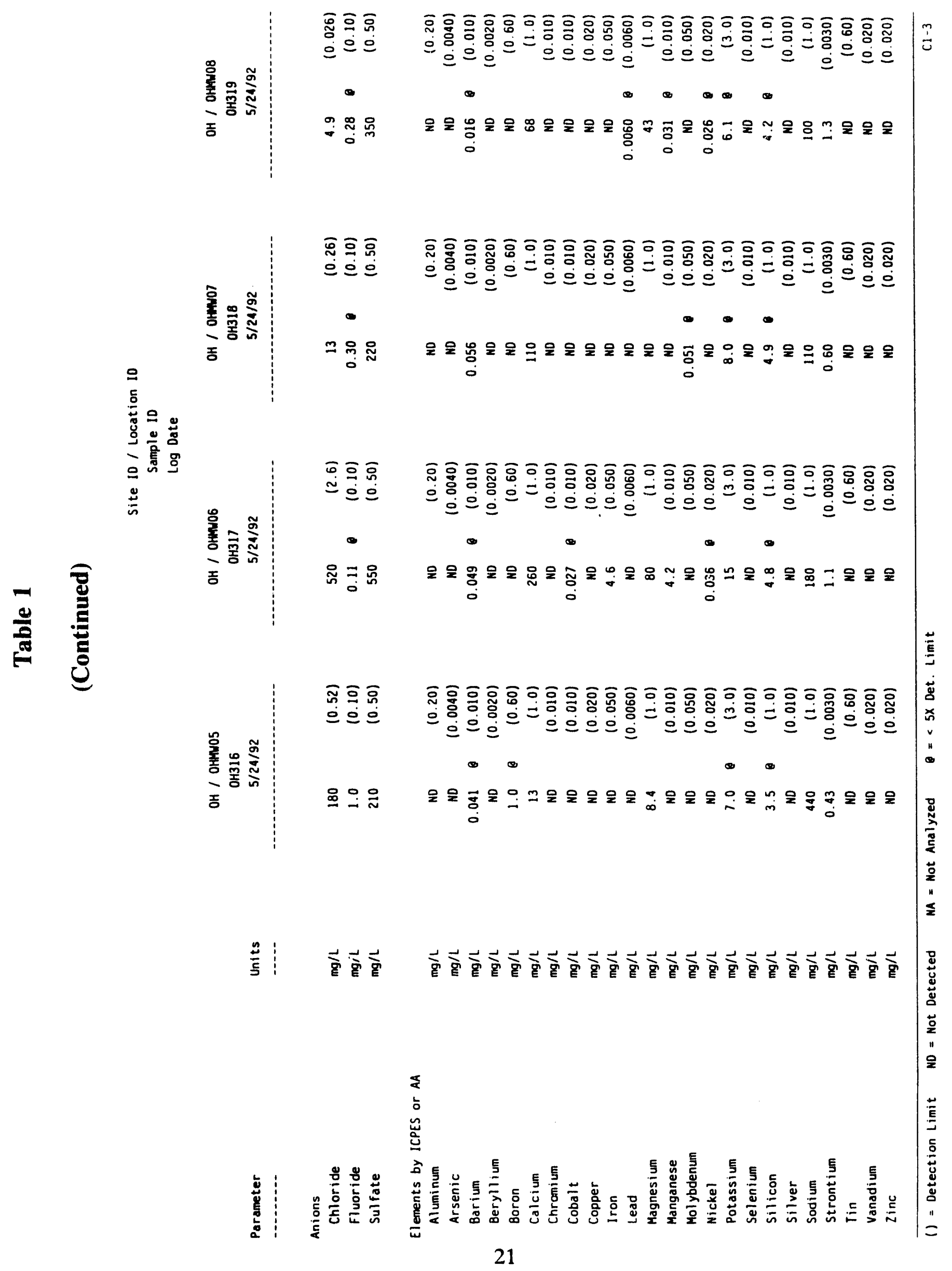




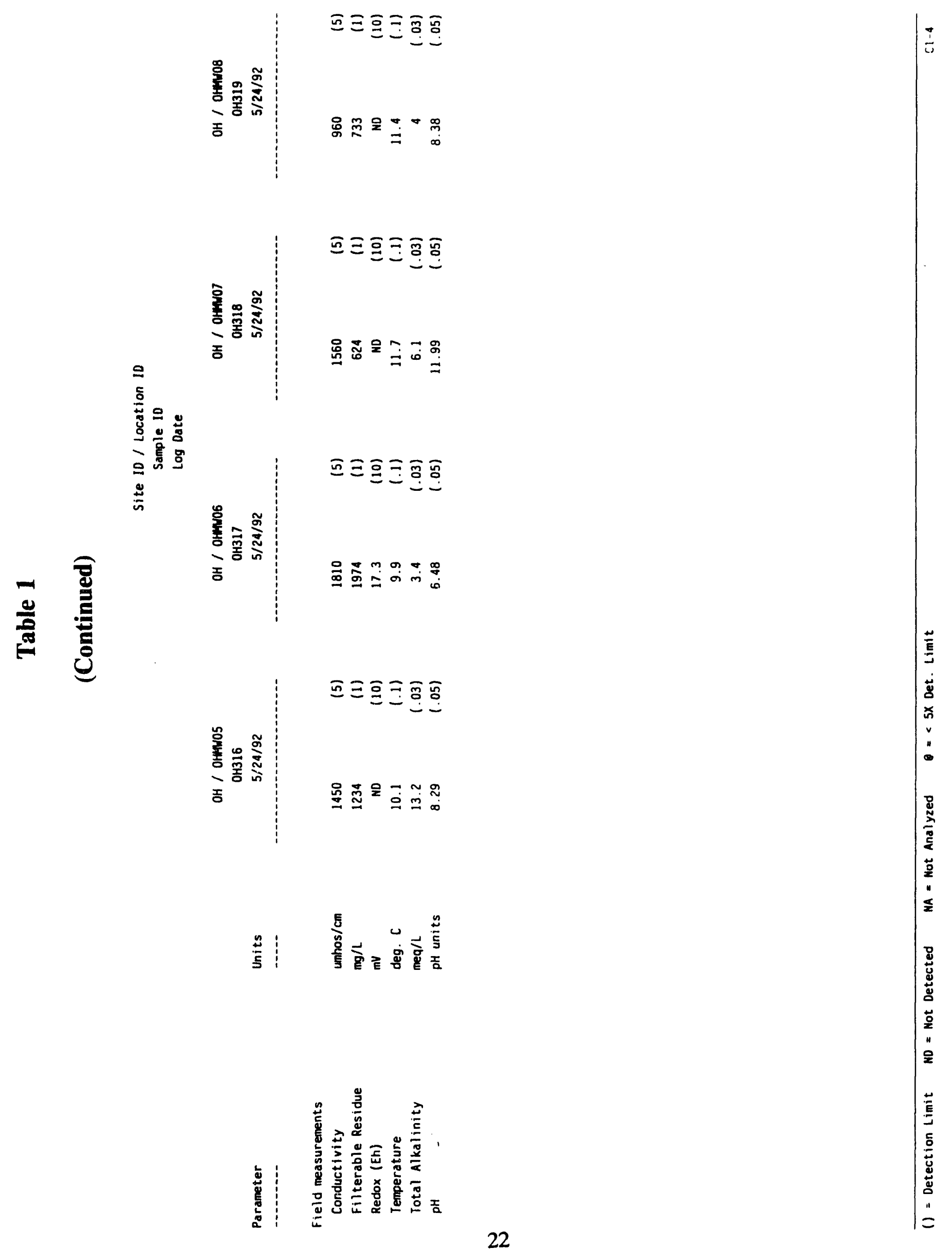




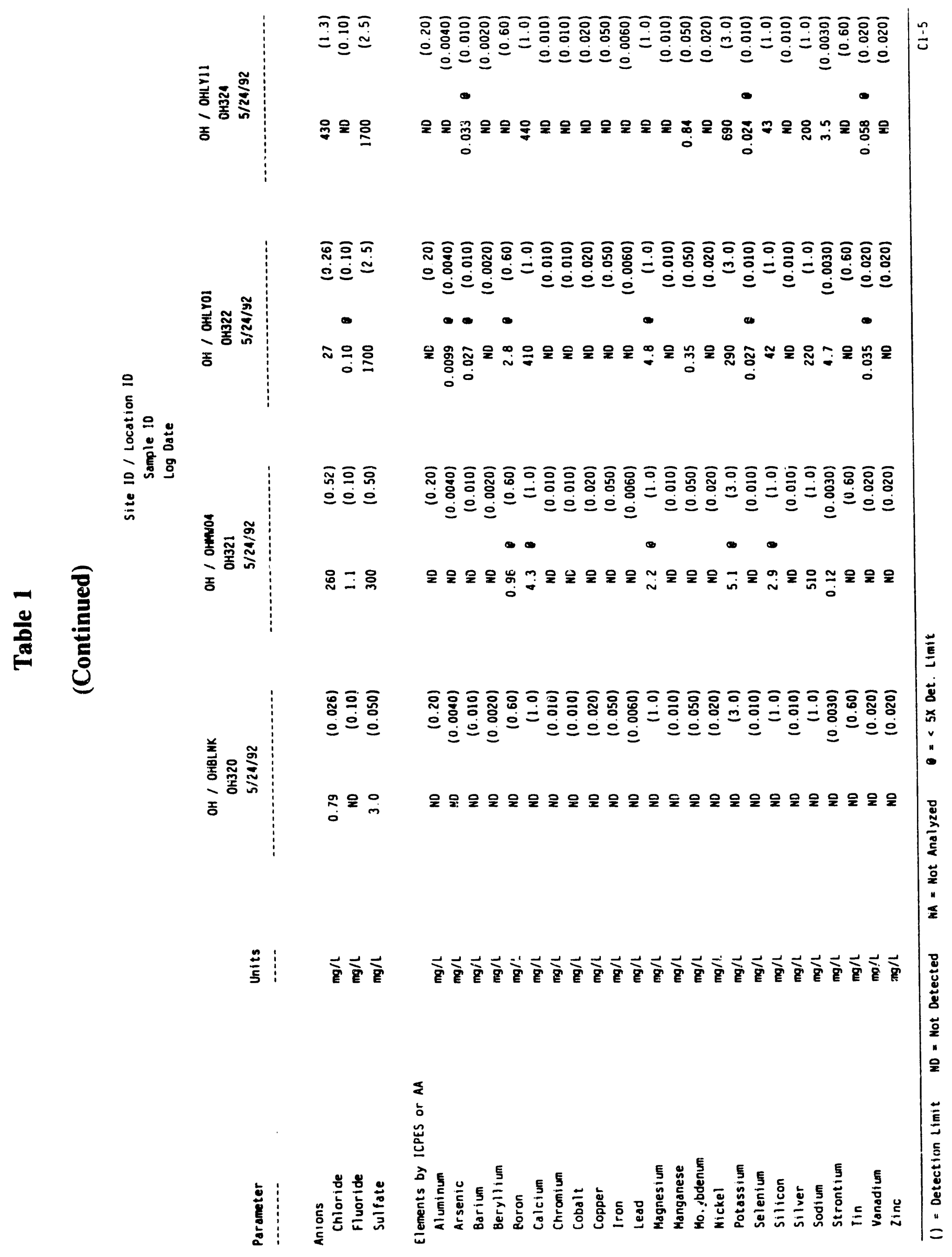




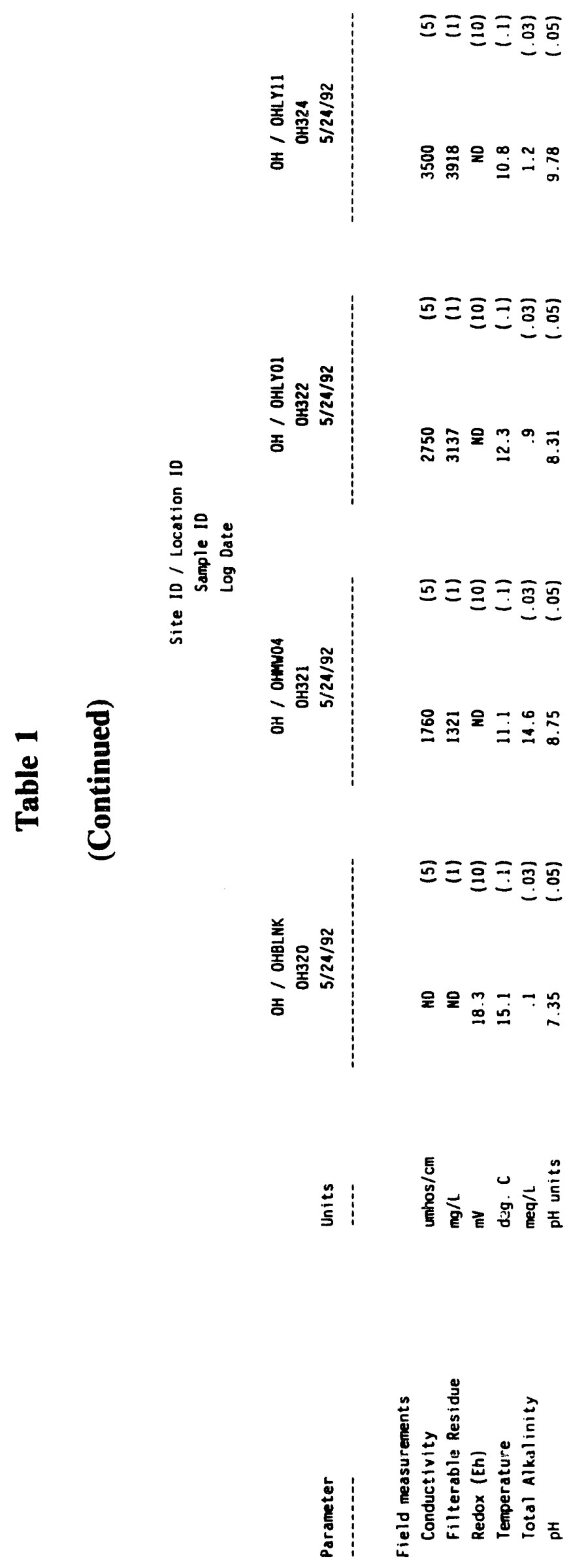




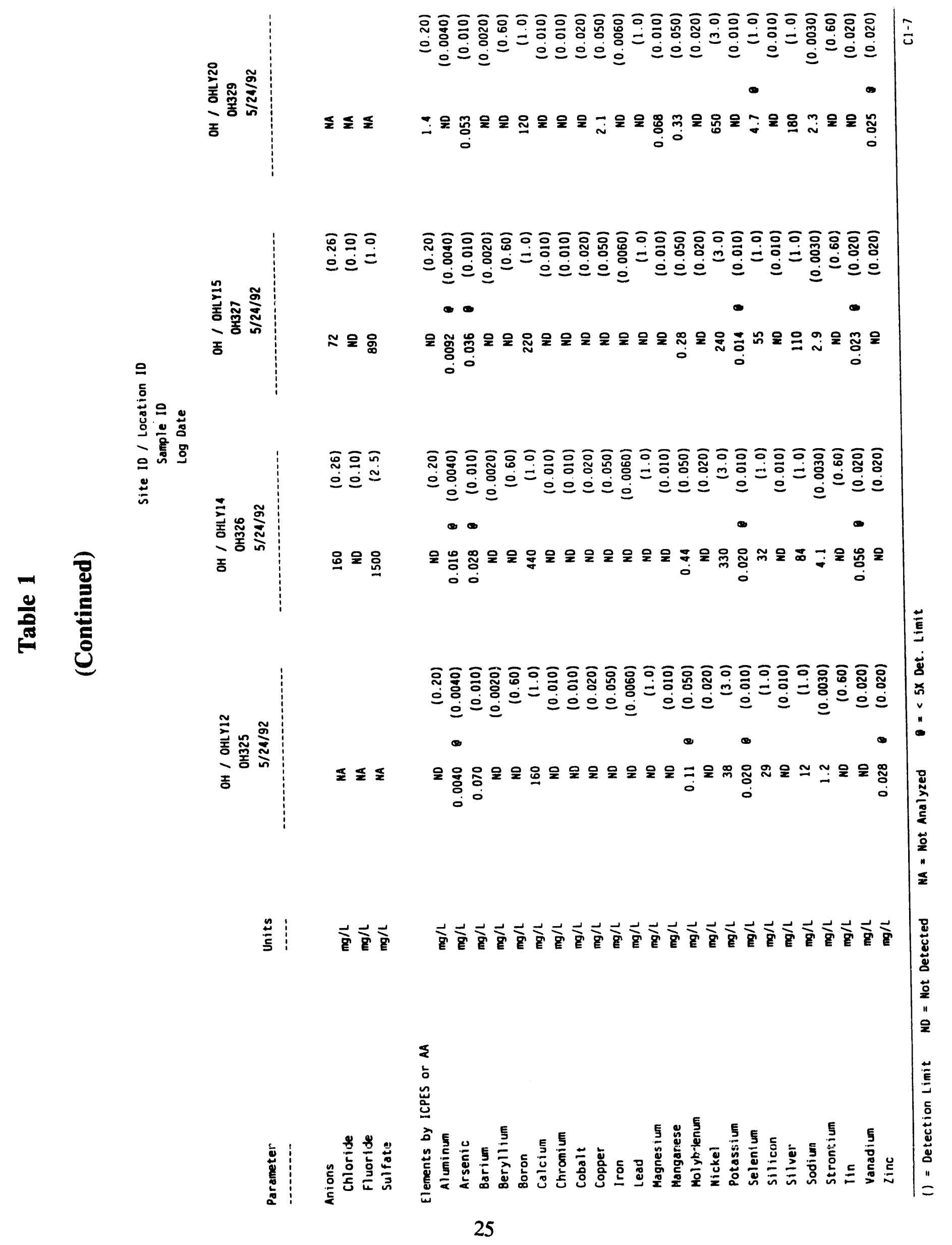




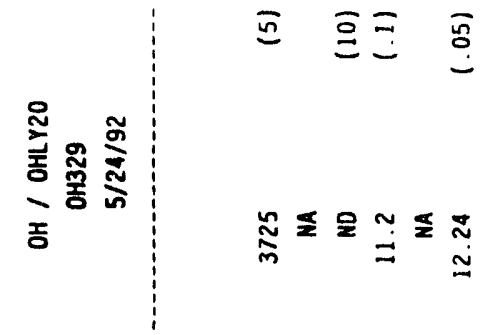

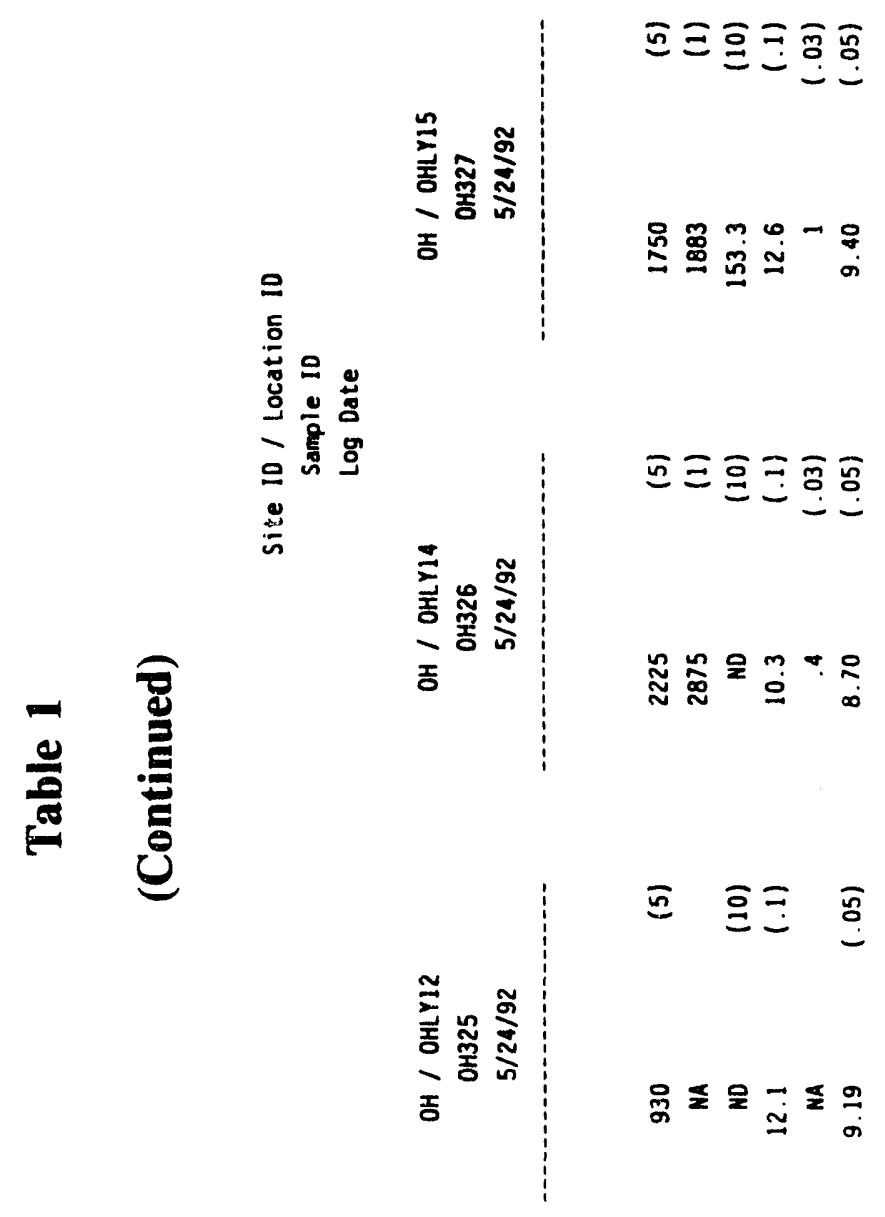

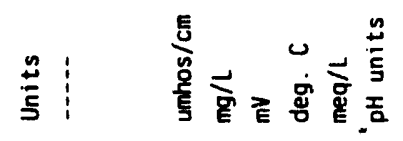

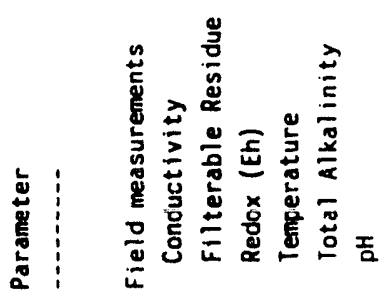




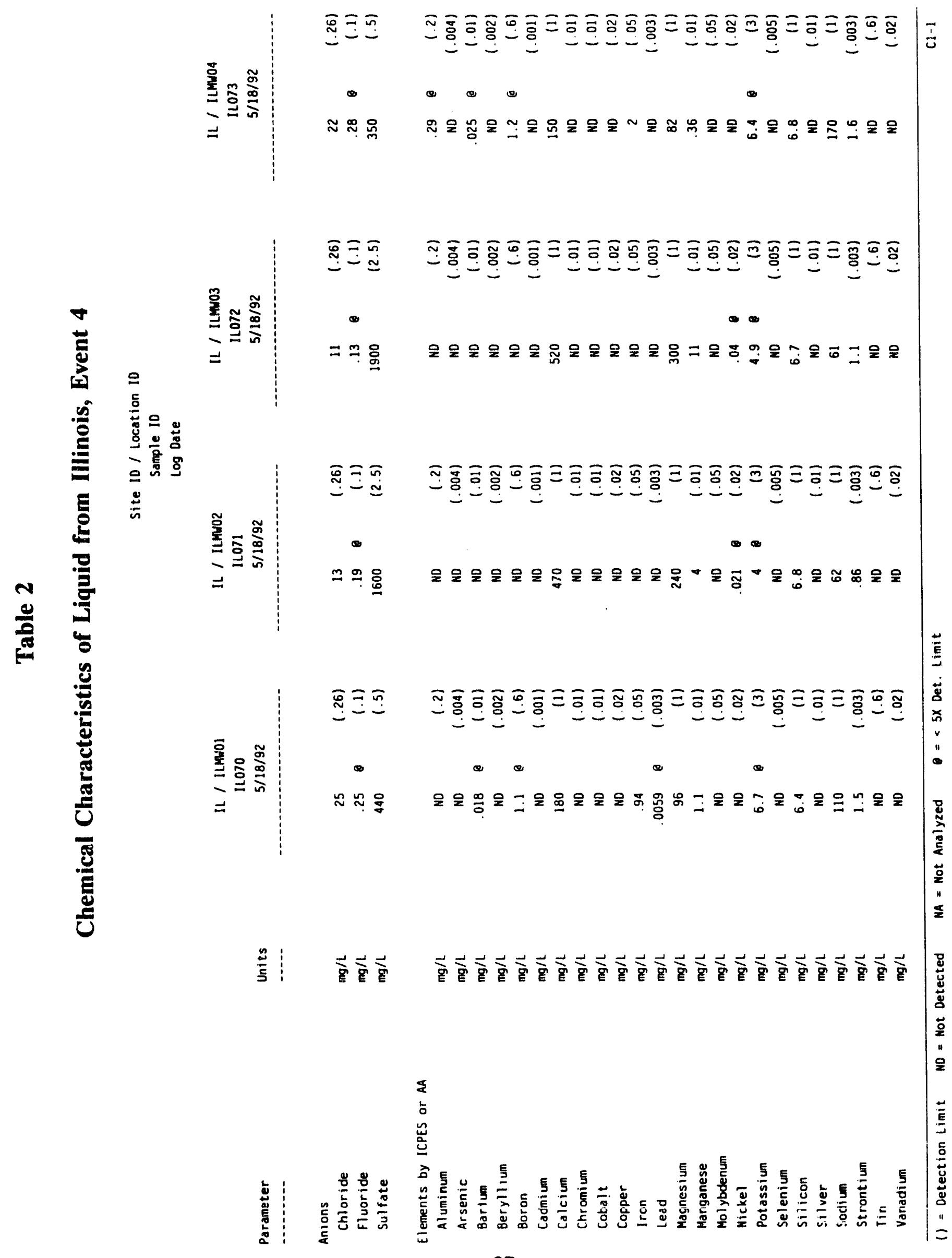




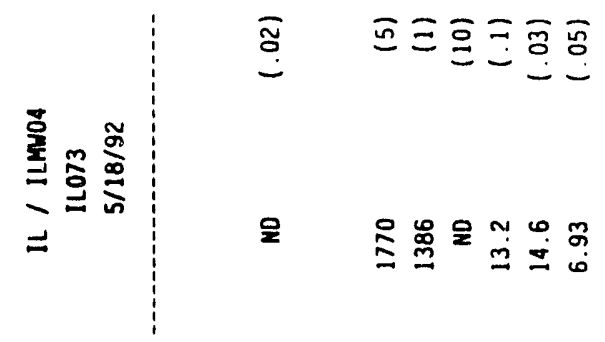

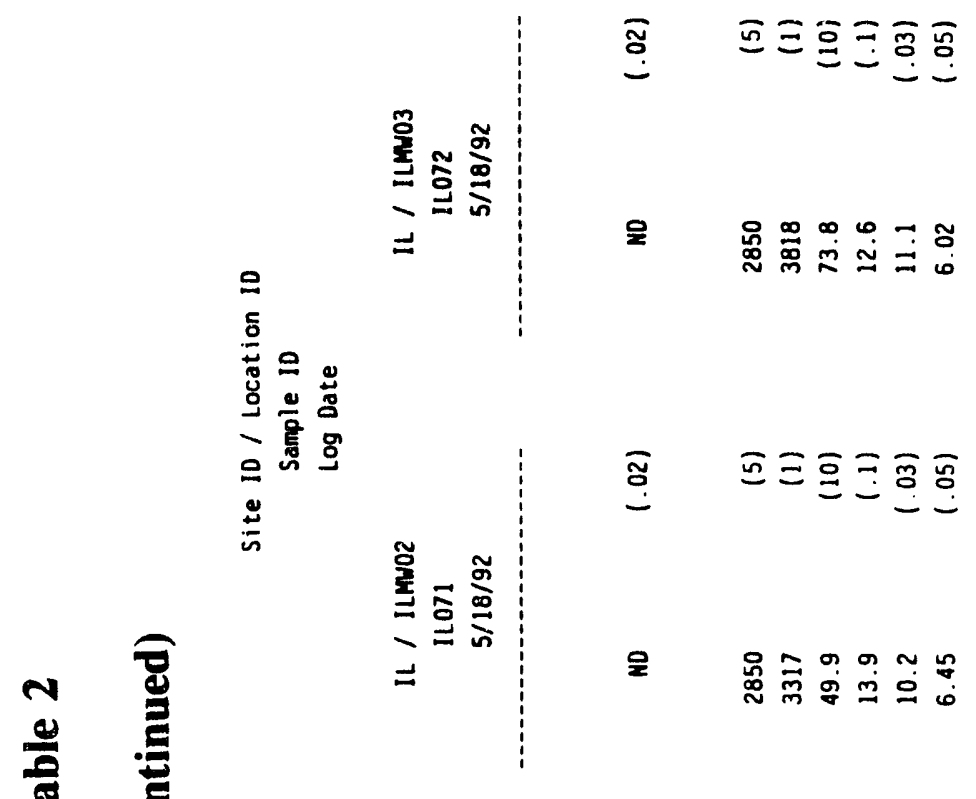

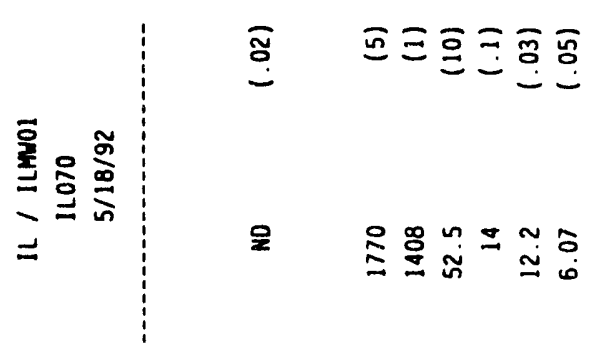

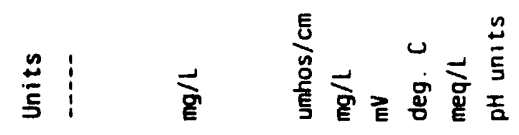

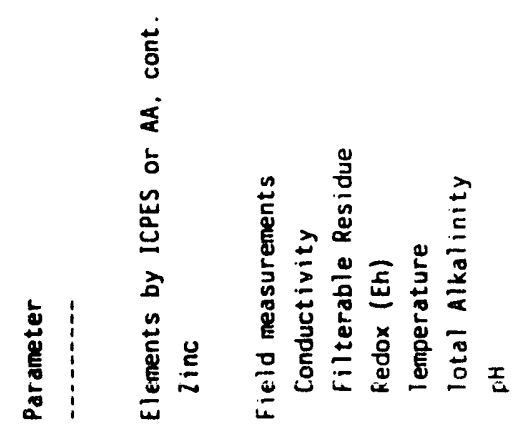




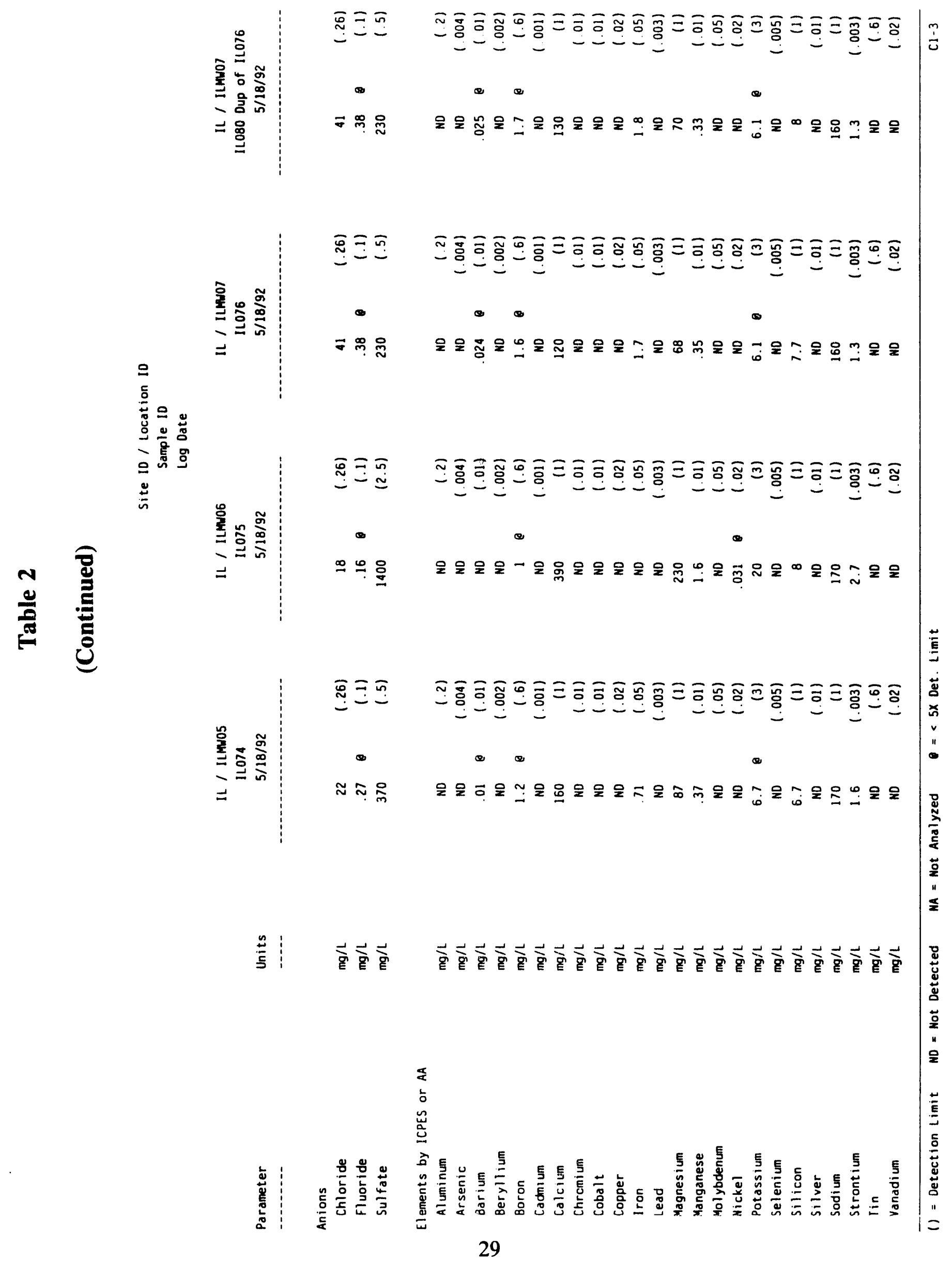




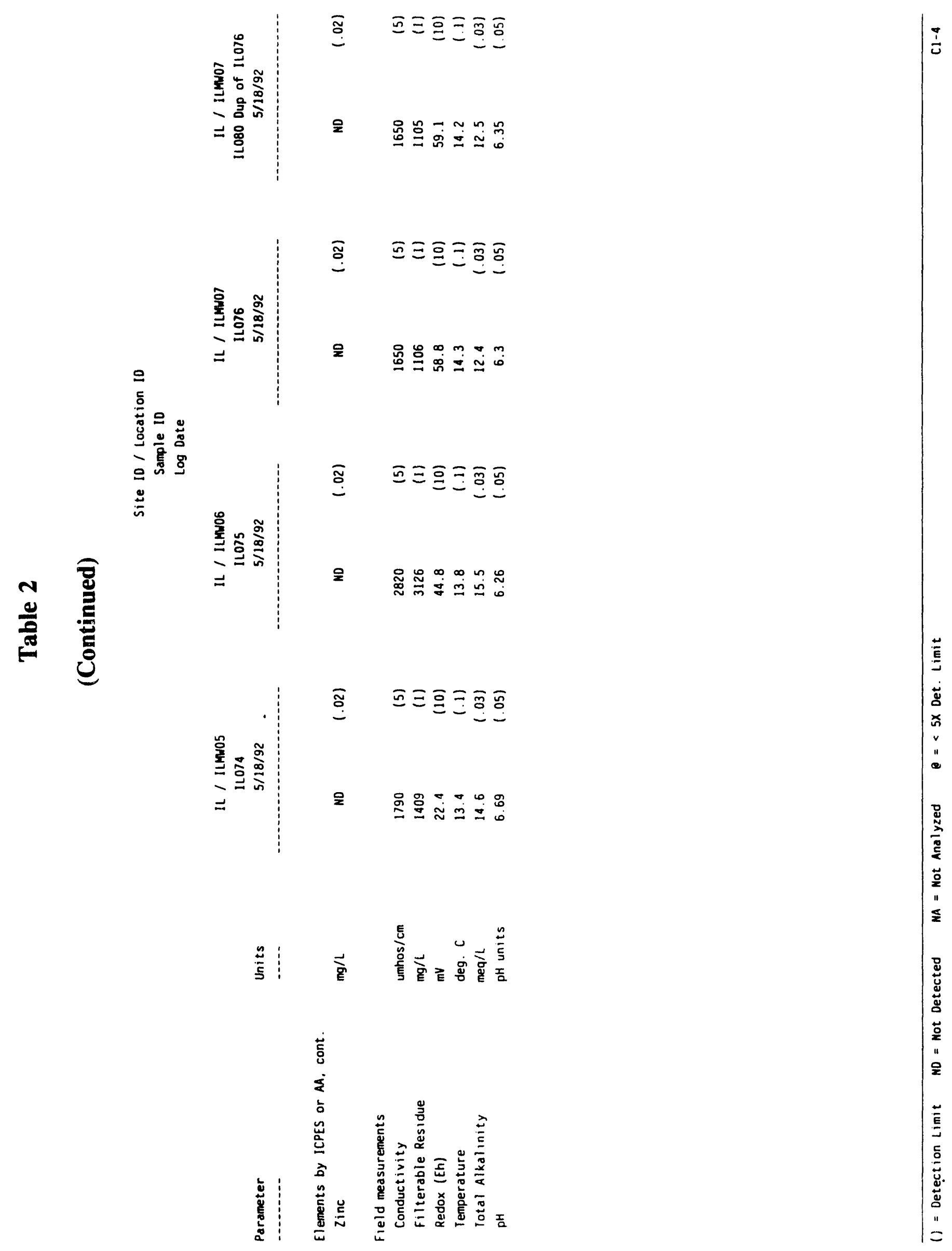




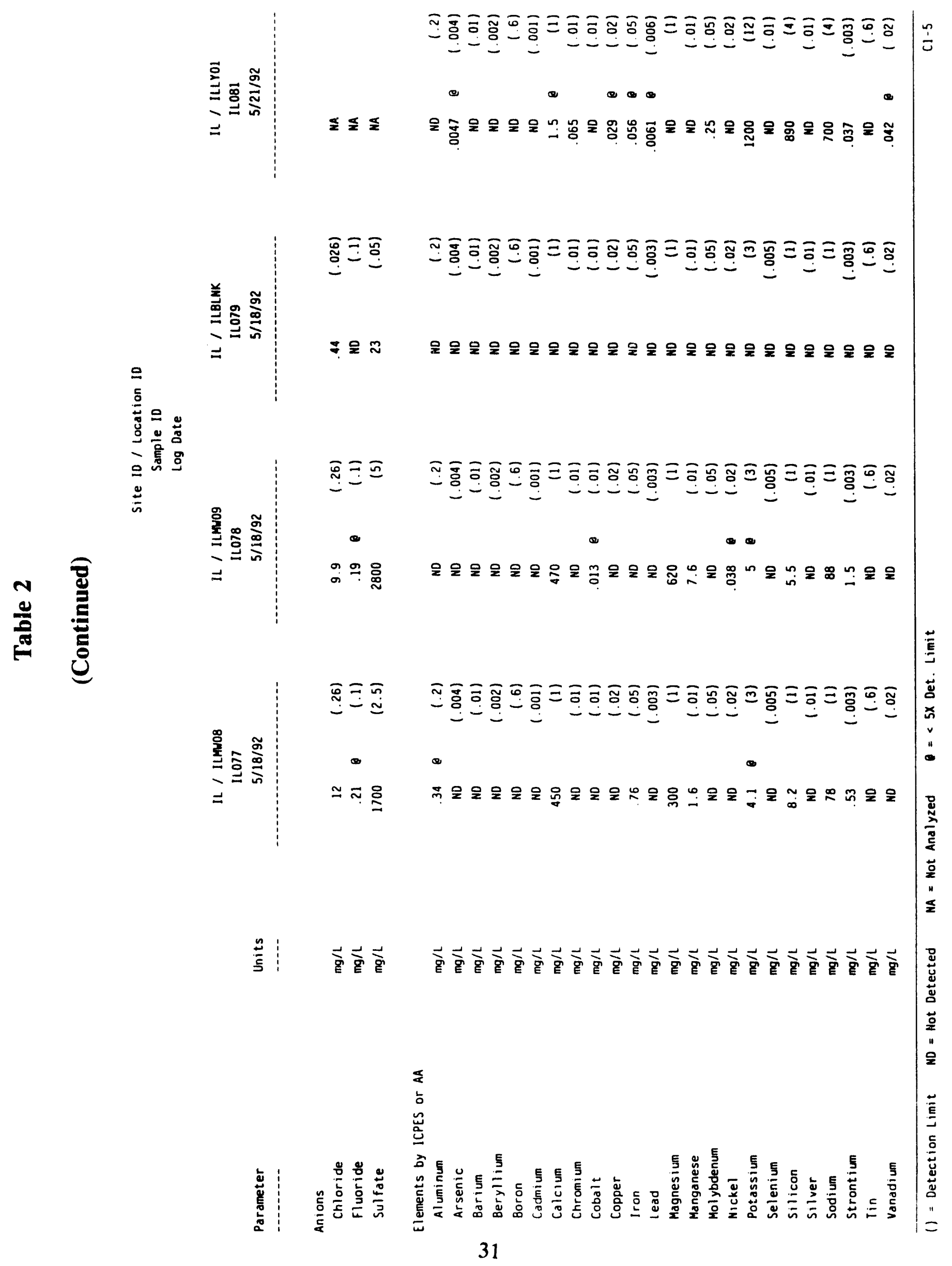




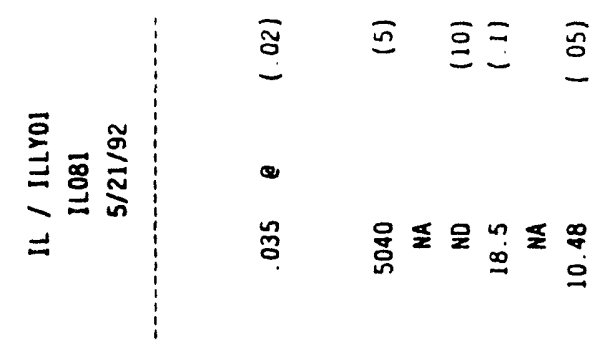

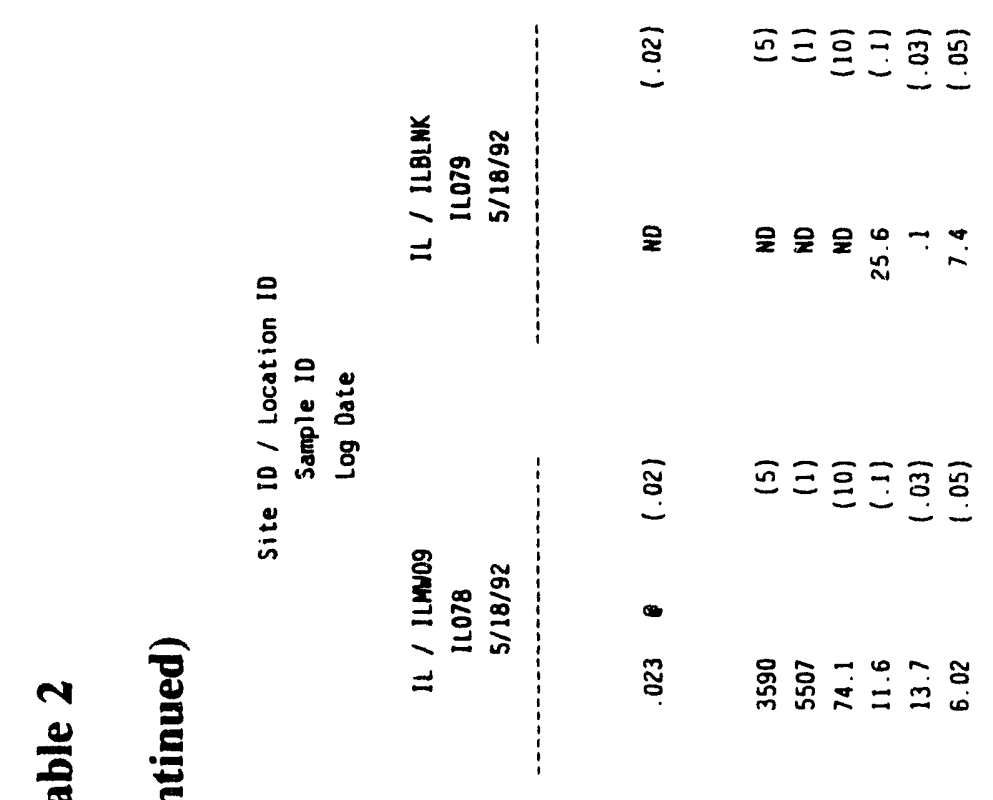

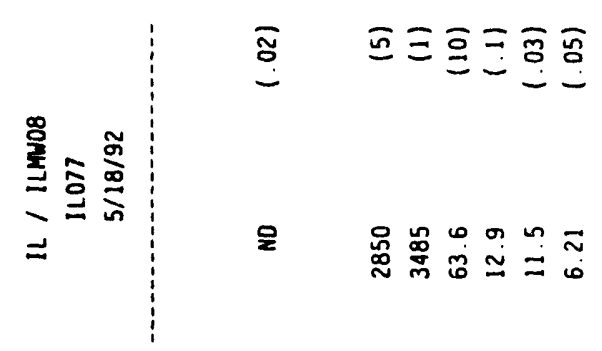

$$
\begin{aligned}
& \text { 岳 }
\end{aligned}
$$

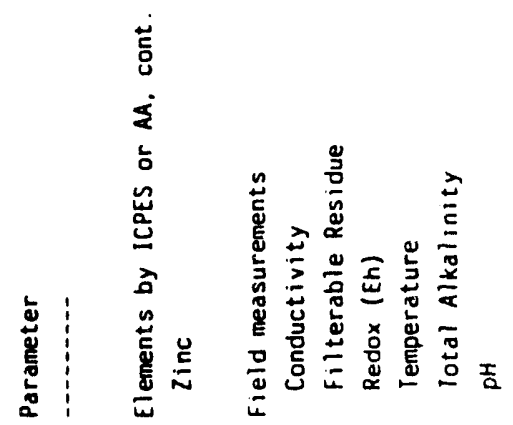




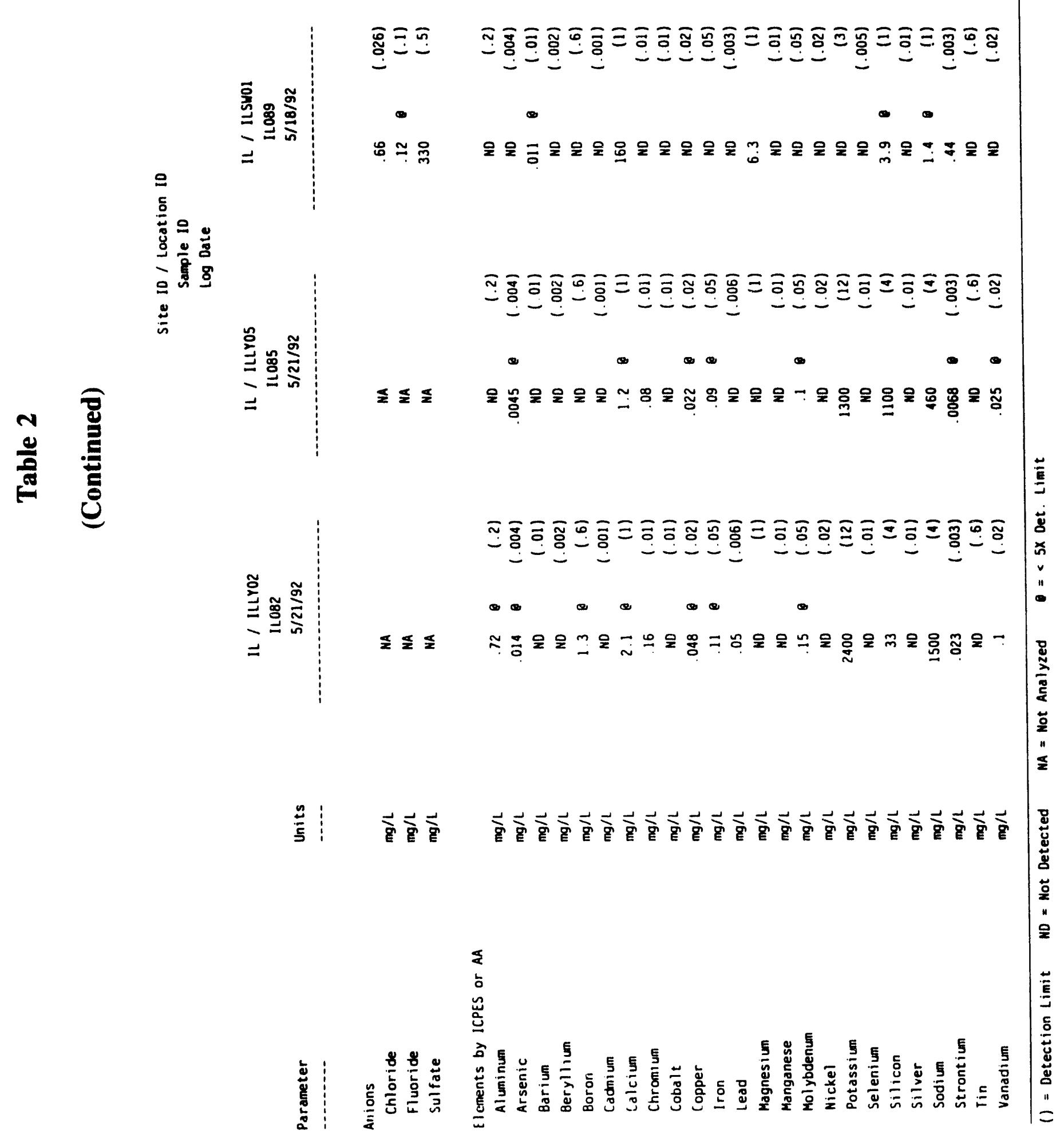




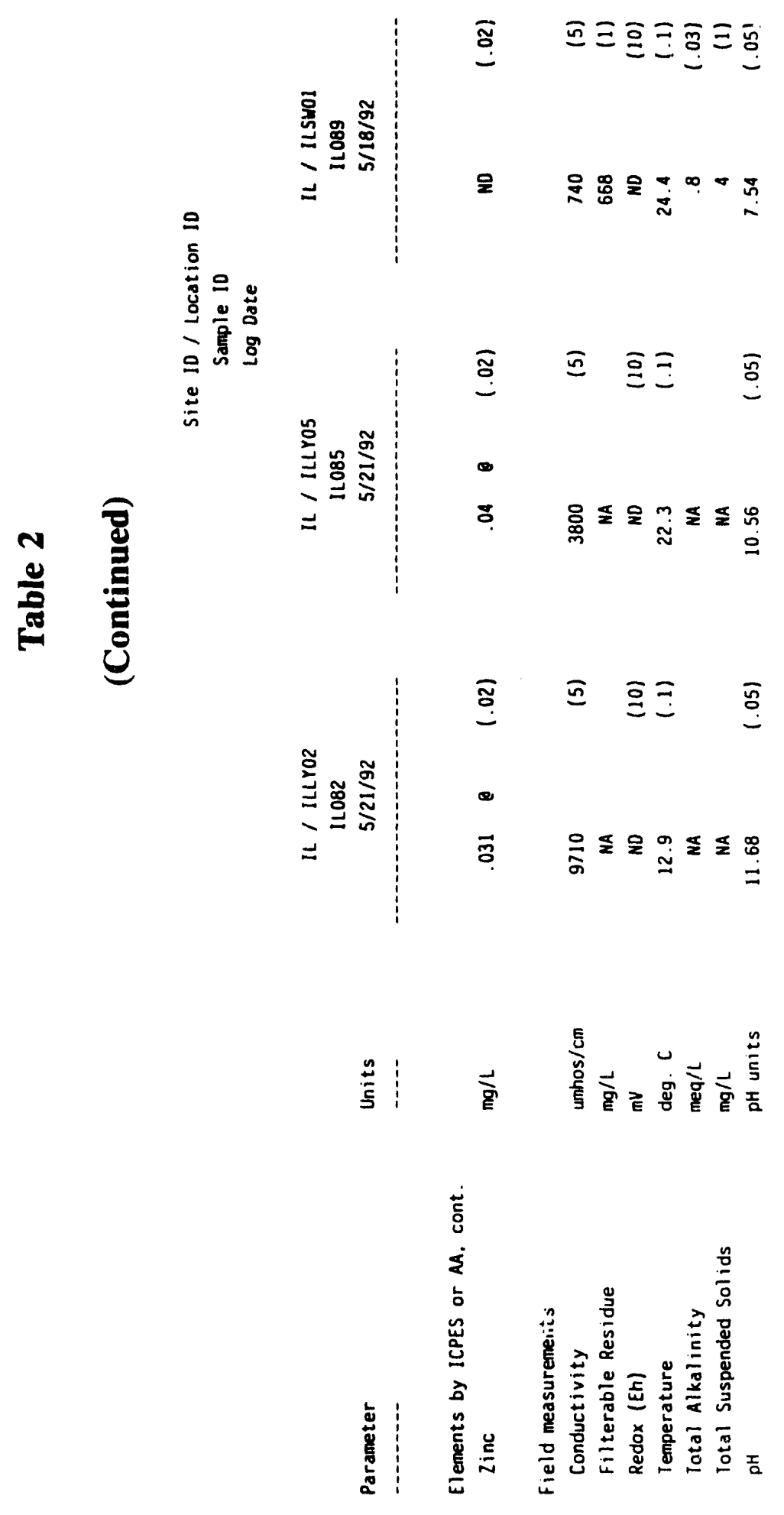




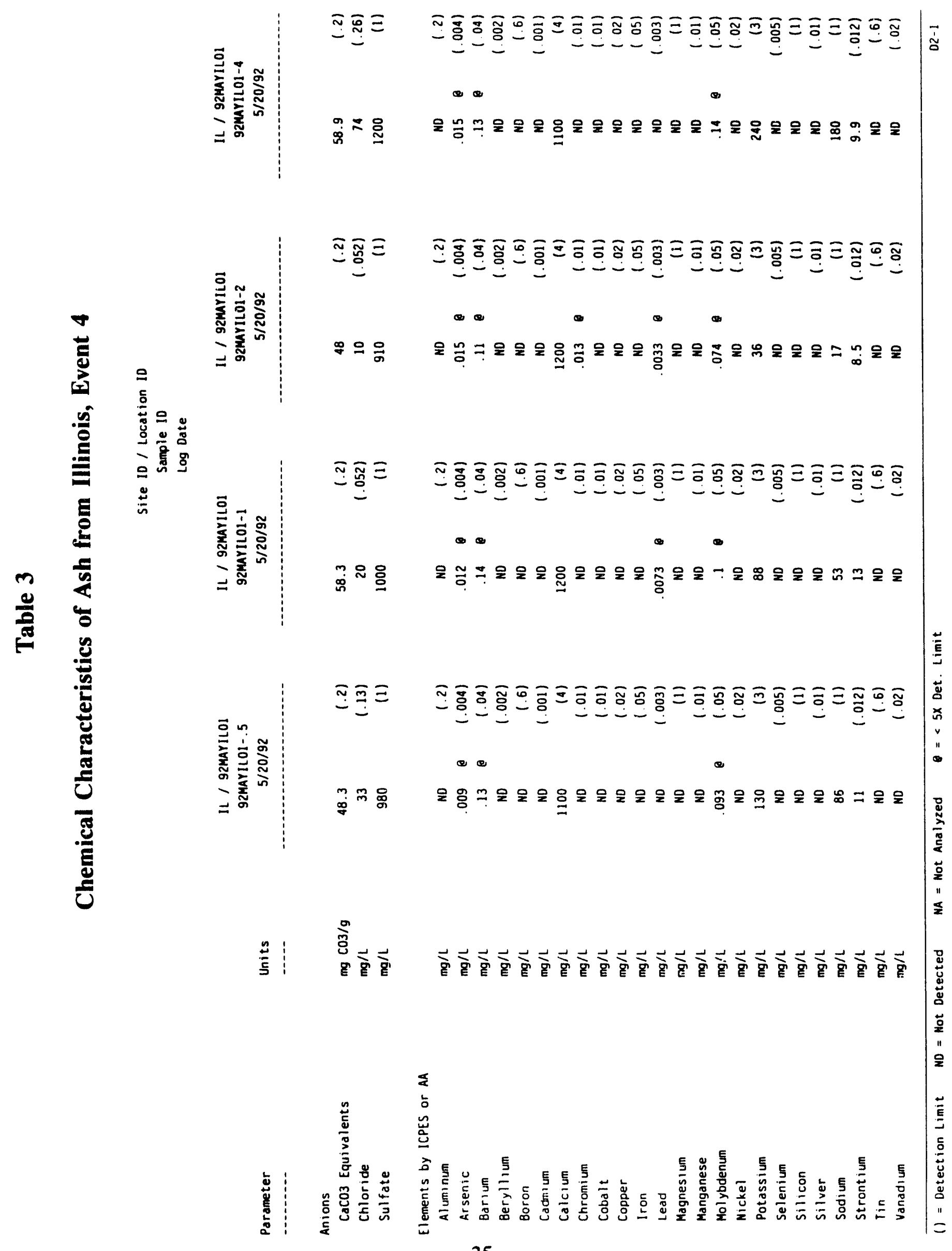


III

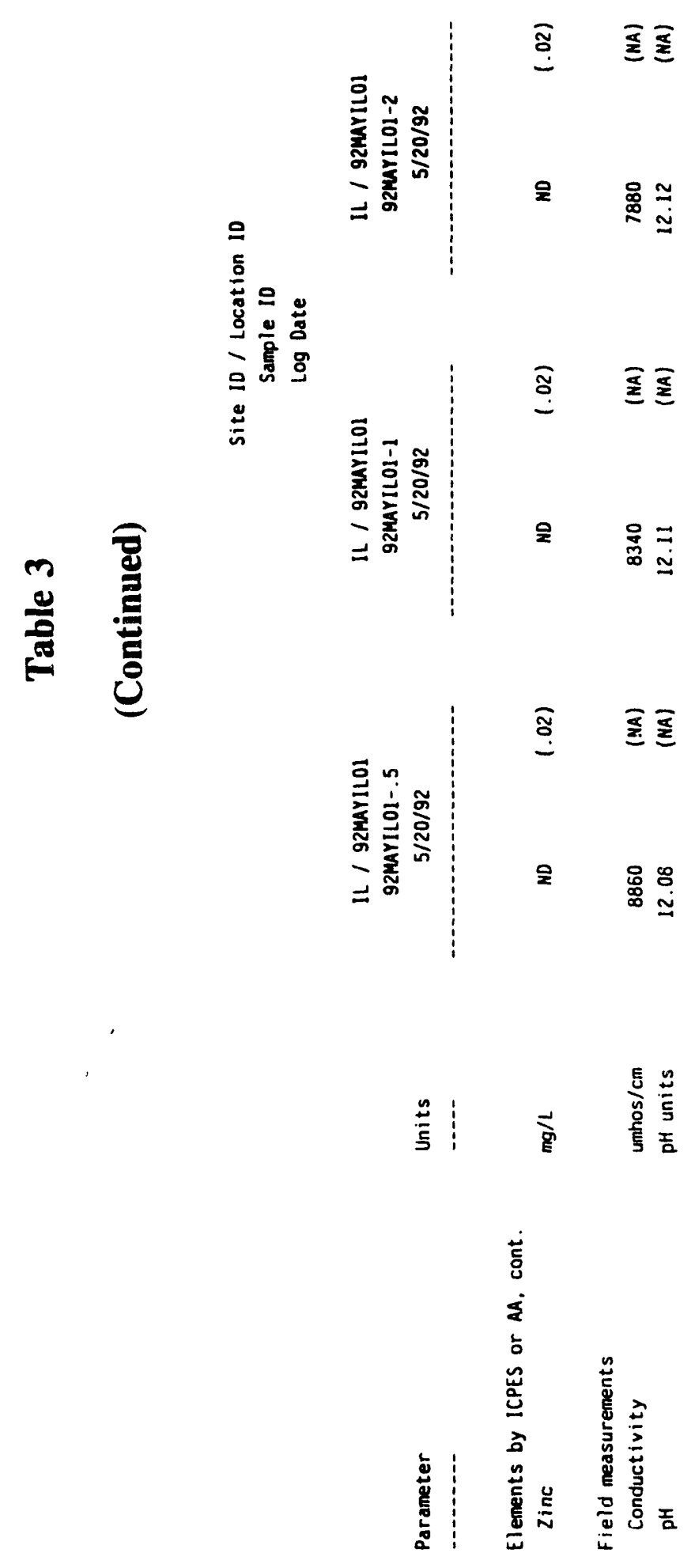




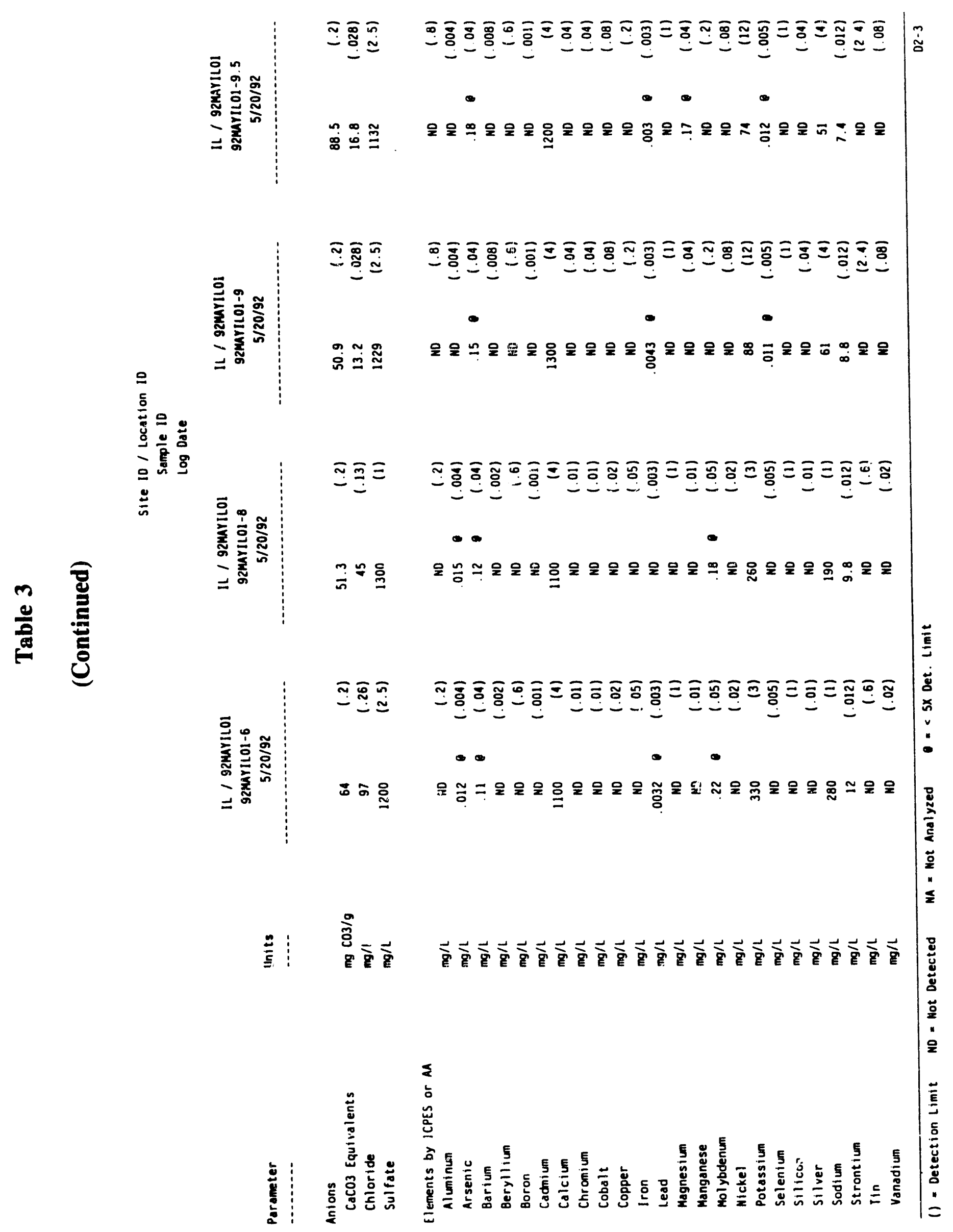



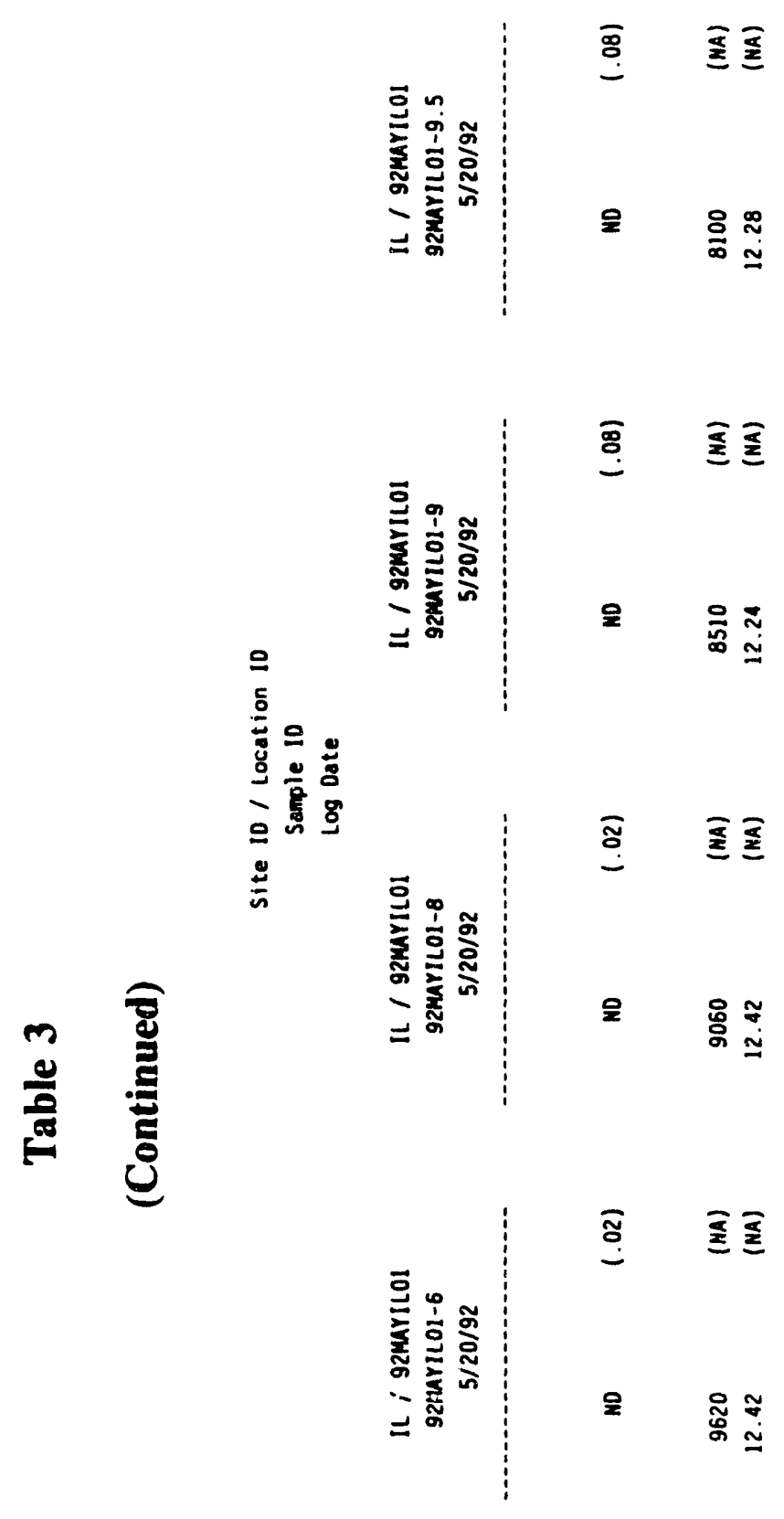

高)

1

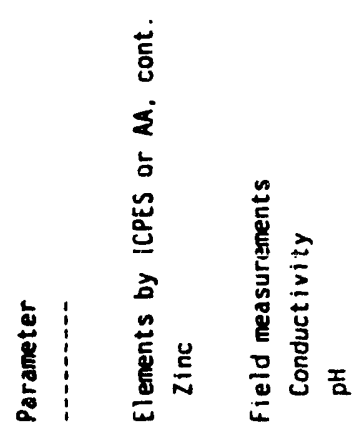



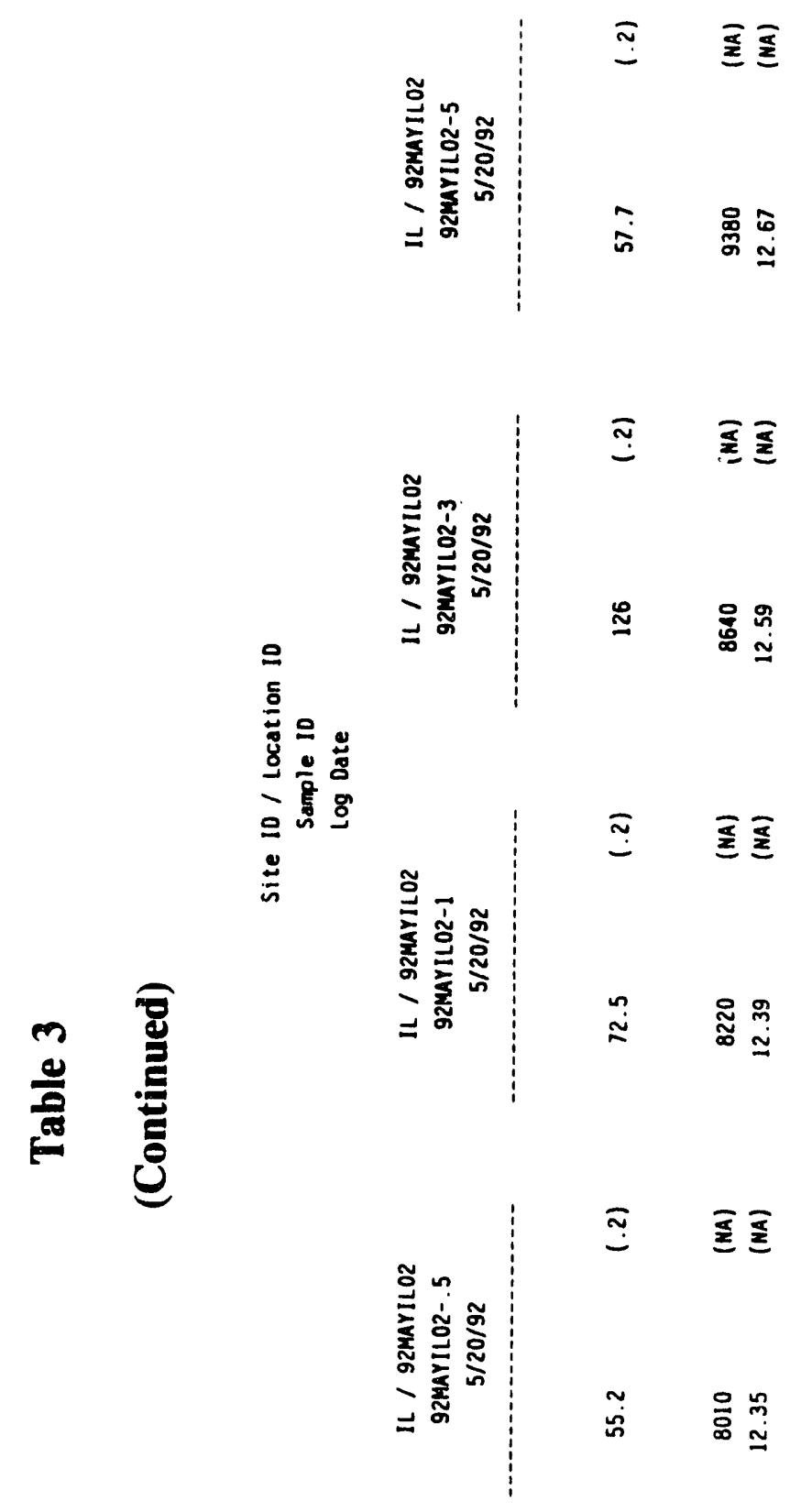

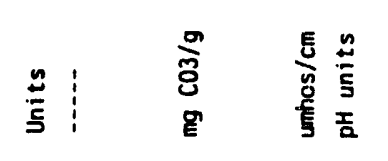




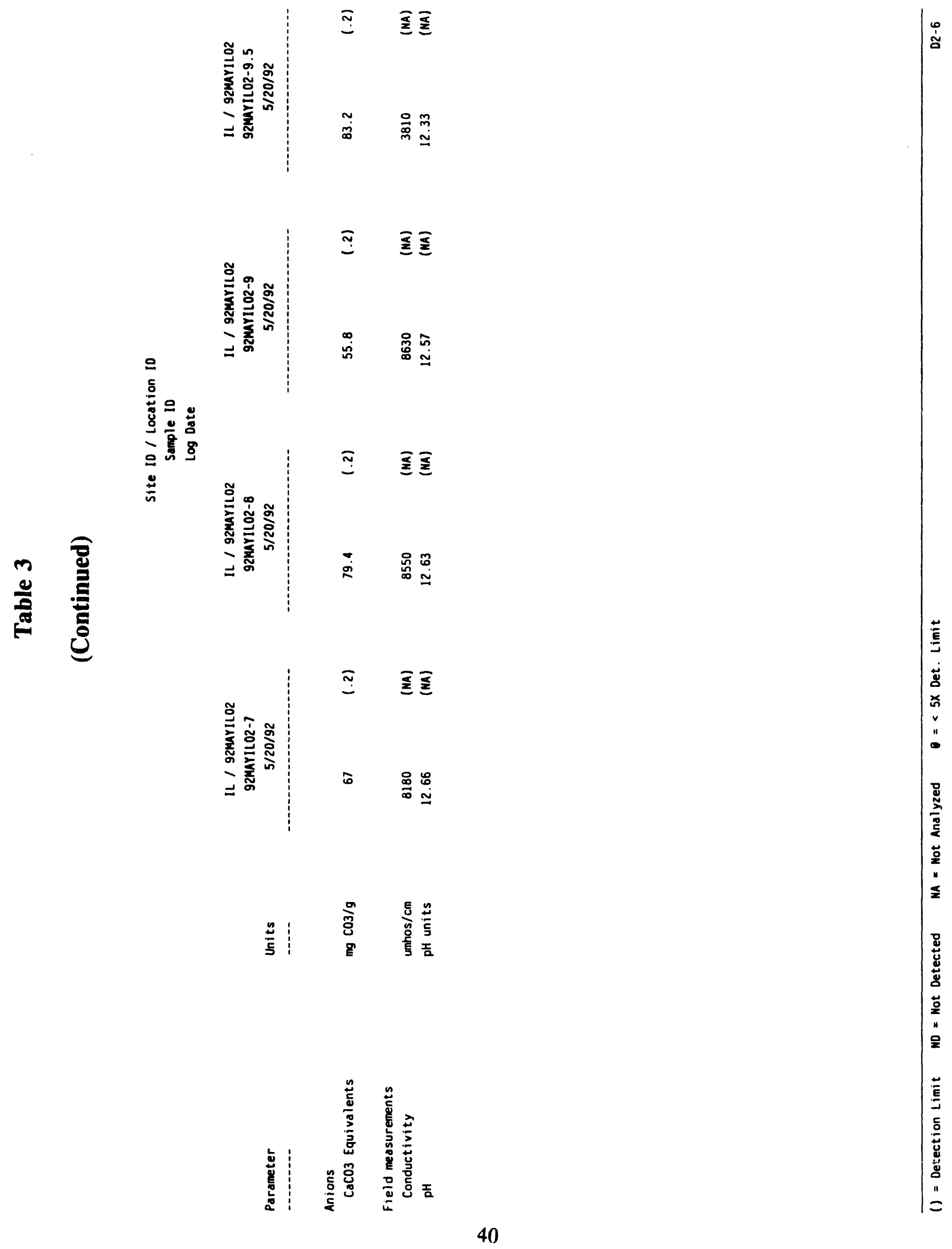




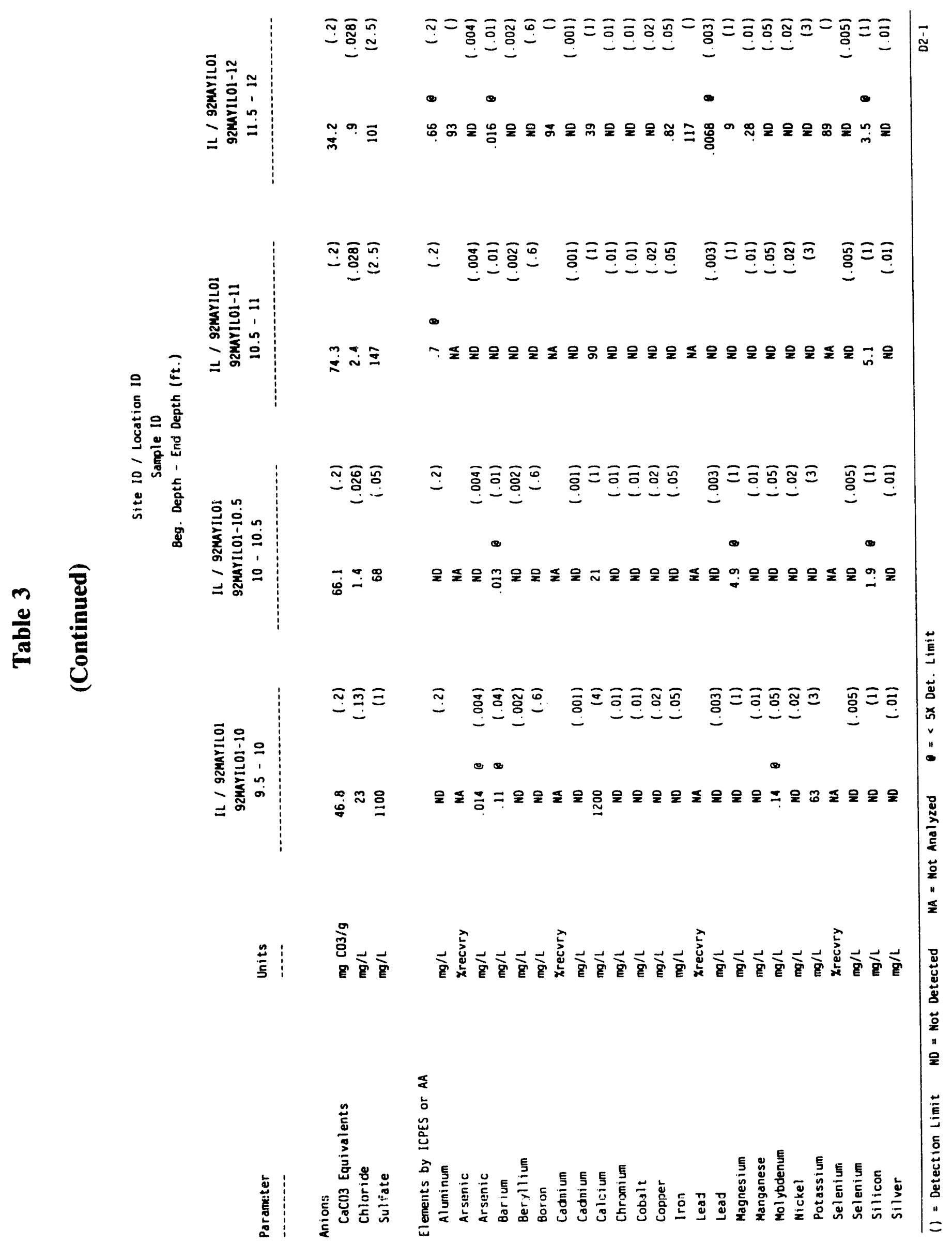




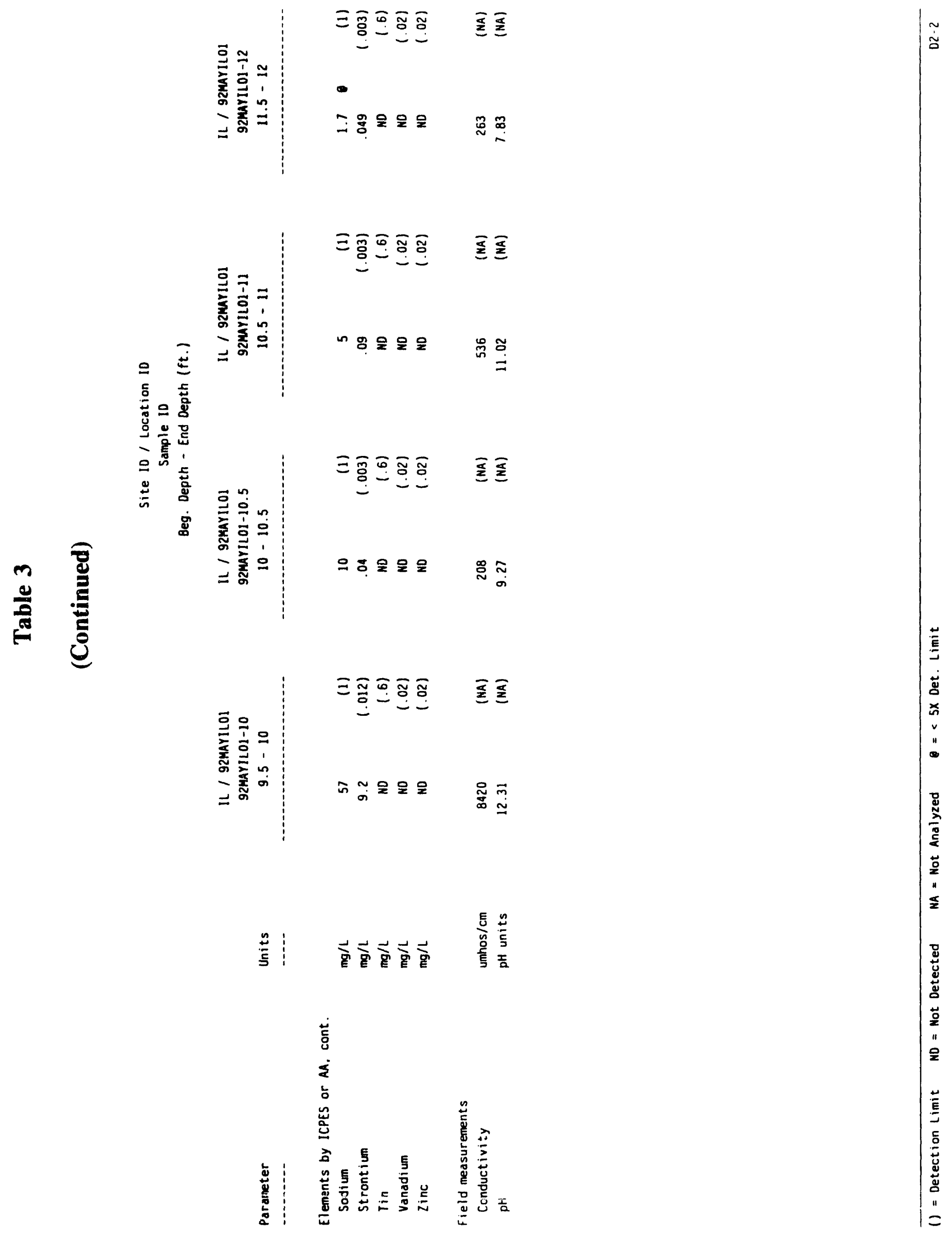




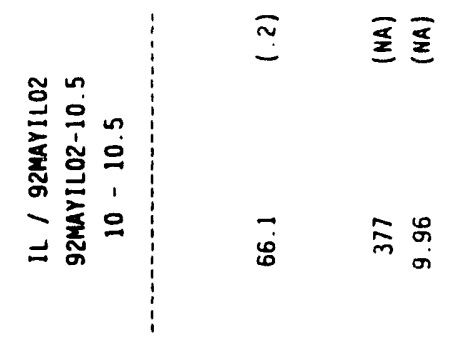

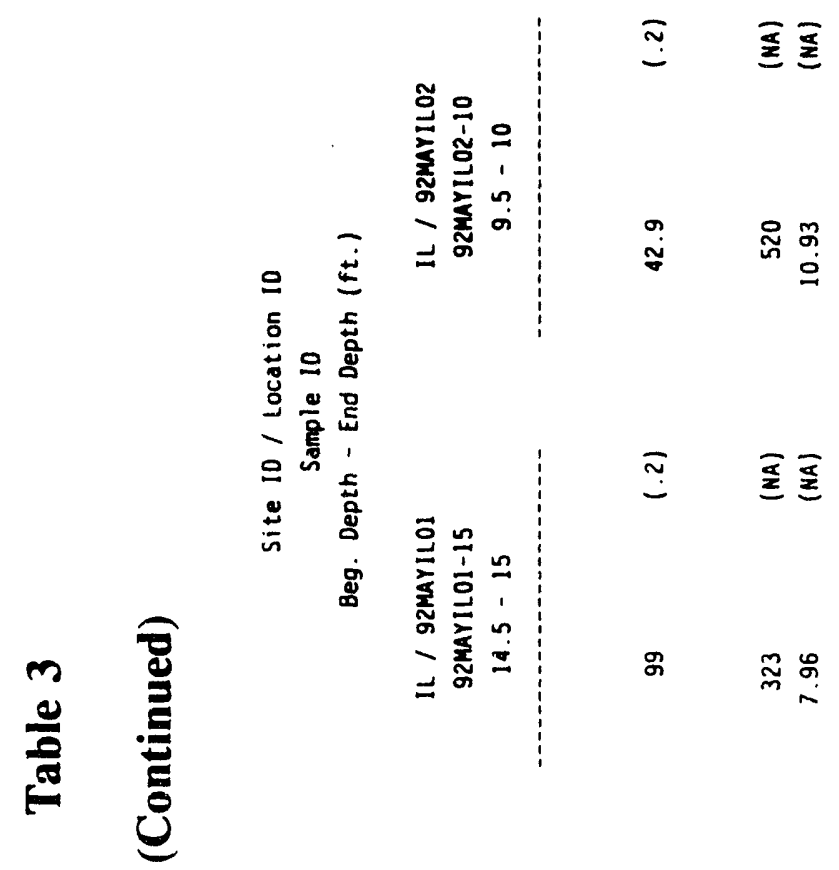

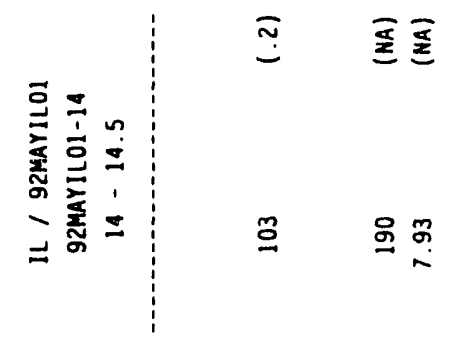

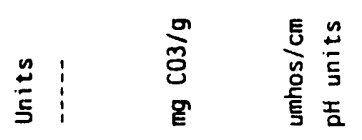

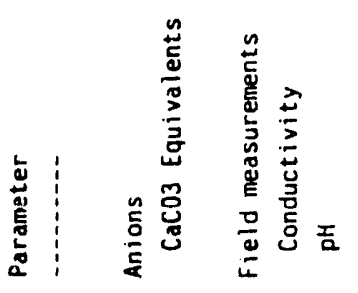




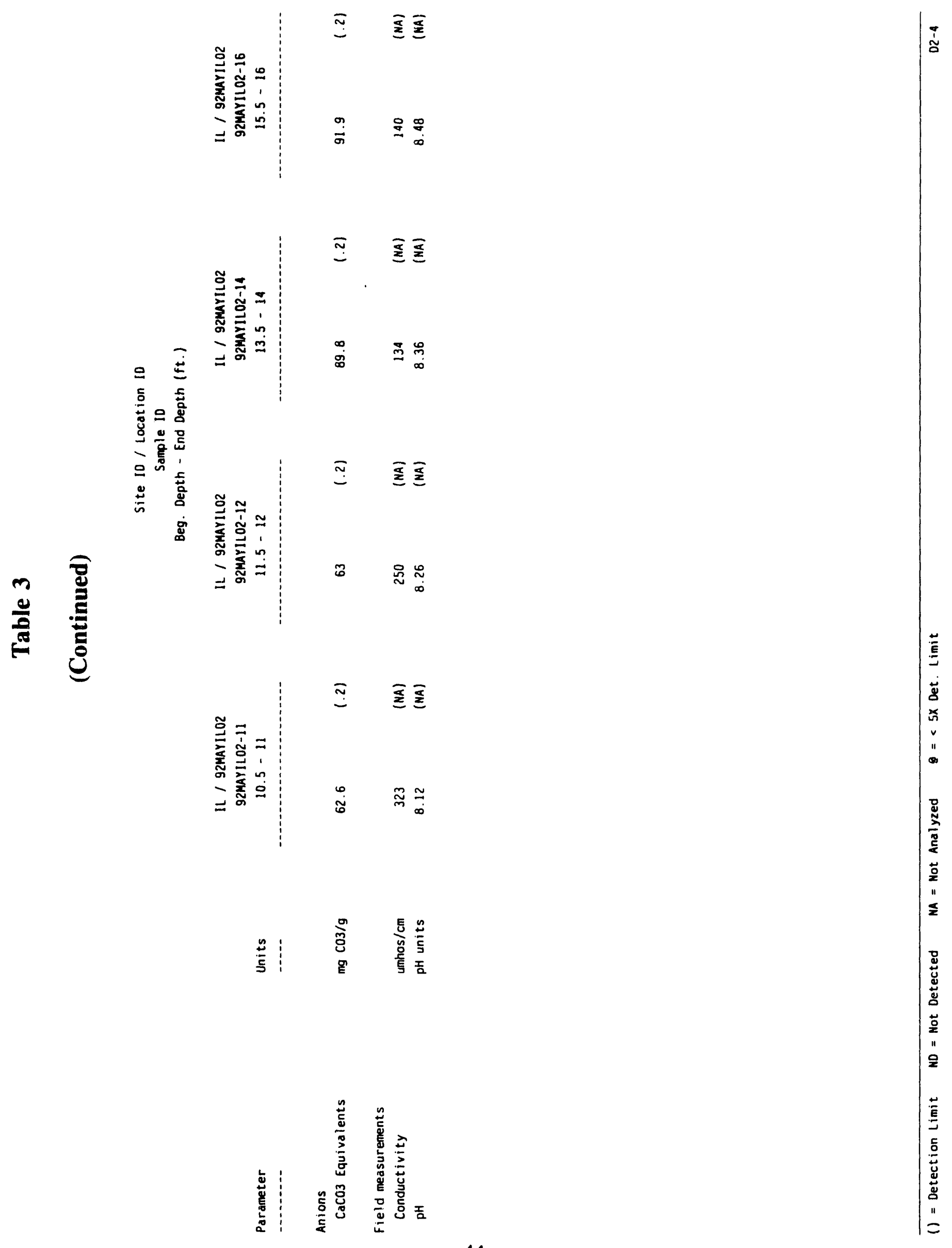


APPENDIX A

Technical Note 


\section{Technical Note:}

\section{Surface Runoff from the Colorado-Ute Landfill Test Cell}

Approximately 800 cubic yards of CFBC wastes from the Colorado Ute Nucla Station are under study in a landfill test cell in Montrose County, Colorado. During the $21 / 2$ years of environmental monitoring at the test site, only one surface water runoff sample has been generated, and the total runoff volume from the $1600 \mathrm{sq}$. ft. test cell during the first year of monitoring, when the cell was uncovered, was less than 5 gallons. Of the 7.5 inches of annual rainfall at the site, nearly $90 \%$ is lost to evaporation; surface runoff is less than $0.2 \%$. Runoff from the test cell is moderately alkaline, with a low dissolved and suspended solids content. Concentrations of all measured species are well below levels of regulatory concern. Data on the chemical analysis of the water and estimates of the amounts of runoff water which might be generated during other rainfall events are detailed below.

The FBC wastes in the landfill test cell were exposed to the elements during the first year after cell construction. During this time a flume was installed at the low point of the cell surface to measure total runoff volumes and to collect water samples for analysis. The total runoff volume measured by the flume during this time was approximately 1.4 gallons, although approximately 4 gallons of water was found in the collection bucket on December 16, 1990. The discrepancy is presumably due to water which trickled into the pail from the flume apron, without passing through the flow meter. Several rain events during late September and early October 1990 are responsible for the runoff water collected in December: the highest daily total rainfall occurred on October 2, 1990 when 1.13 inches of rain was measured at the site; the heaviest hourly rainfall occurred on September 17, 1990 when 0.42 inches of rain fell in one hour. 
The low volume of runoff from the landfill test cell is related both to the generally dry climate of the site, and to the relatively high permeability of the waste surface, which allows most of the rainfall to be absorbed into the upper layers of the FBC wastes. Field measurements of the near-surface permeability of the Colorado FBC waste in December 1990 average $8.17 \times 10^{-4} \mathrm{~cm} / \mathrm{sec}$, or $1.16 \mathrm{in} / \mathrm{hr}$. This permeability appears to be sufficient to absorb rainfall from most events except heavy downpours. HELP model $^{1}$ predictions, based on climate data for Grand Junction with annual rainfall of 7.55 inches and a soil hydraulic conductivity of $1.00 \mathrm{in} / \mathrm{hr}$, show nearly $90 \%$ of the water budget is lost to evaporation, with runoff accounting for less than $0.2 \%$. At the Colorado site, absorbed rainfall is largely evaporated from the waste surface.

The composition of the single runoff sample collected from the Colorado site is shown in Table 1. The major inorganic components of the runoff water are calcium and sulfate, which are present at concentrations of 67 and $160 \mathrm{mg} / \mathrm{L}$, respectively. Low concentrations of other common species including chloride, fluoride, magnesium and sodium are also present in the sample. Barium, strontium, lead and zinc were also detected in the runoff, while cadmium was found at the detection limit concentration. Some organic activity has probably taken place in the sample bucket between the time of the runoff events and the sample collection. The total organic carbon concentration of the sample is $460 \mathrm{mg} / \mathrm{L}$, both nitrate and ammonia are present, and the oxidation-reduction potential is considerably lower than would be expected for a fresh runoff sample, all indicative of biological activity. The $\mathrm{pH}$ of the sample was measured as 9.01 ; this measurement may have been affected by bacterial action in the sample pail. Approximately $65 \mathrm{mg} / \mathrm{L}$ suspended solids are also present in the runoff.

The data available from the Colorado Ute landfill test cell suggest that only very intense rainfall events could produce significant volumes of runoff from the landfilled FBC wastes, given the climatic conditions at the site and the waste perme-

${ }^{1}$ The Hydrologic Evaluation of Landfill Performance (HELP) Model. P.R. Schroeder, A.C. Gibson, and M.D. Smolen, 1984b. U.S. EPA/530-SW-84-010. 
ability. Such events will produce runoff with a low total dissolved solids load, since under such conditions there is a high dilution factor and runoff is rapid. The chemistry of the only runoff sample collected from the test cell is consistent with these conclusions. 
Table 1

\section{Colorado Runoff Composition}

\begin{tabular}{|c|c|c|c|}
\hline Analyte & Result & Units & $\begin{array}{l}\text { Detection } \\
\text { Limit }\end{array}$ \\
\hline $\begin{array}{l}\text { Field Measurements: } \\
\text { Alkalinity } \\
\text { Conductivity } \\
\text { pH } \\
\text { Redox vs. } \mathrm{Ag} / \mathrm{Agcl} \\
\text { Temperature } \\
\end{array}$ & $\begin{array}{c}\text { ND } \\
2025 .^{*} \\
9.01 \\
-123 \\
19 \\
\end{array}$ & $\begin{array}{c}\text { meq } / \mathrm{L} \\
\mu \mathrm{mhos} / \mathrm{cm} \\
\mathrm{pH} \text { units } \\
\mathrm{mV} \\
\text { degrees } \mathrm{C}\end{array}$ & $\begin{array}{l}1 \\
-- \\
-- \\
-- \\
--\end{array}$ \\
\hline $\begin{array}{l}\text { Water Quality Parameters: } \\
\text { Total Dissolved Solids } \\
\text { Total Organic Carbon } \\
\text { Total Phenolics } \\
\text { Total Suspended Solids } \\
\end{array}$ & $\begin{array}{c}305 \\
460 \\
.006 \\
64.7 \\
\end{array}$ & $\begin{array}{l}\mathrm{mg} / \mathrm{L} \\
\mathrm{mg} / \mathrm{L} \\
\mathrm{mg} / \mathrm{L} \\
\mathrm{mg} / \mathrm{L}\end{array}$ & $\begin{array}{c}.5 \\
10 \\
.005 \\
.5 \\
\end{array}$ \\
\hline $\begin{array}{l}\text { Anions: } \\
\text { Ammonia as } \mathrm{N} \\
\text { Chloride } \\
\text { Fluoride } \\
\text { Nitrate-Nitrite as } \mathrm{N} \\
\text { Sulfate } \\
\end{array}$ & $\begin{array}{c}.52 \\
2.9 \\
.52 \\
1.1 \\
160 \\
\end{array}$ & $\begin{array}{l}\mathrm{mg} / \mathrm{L} \\
\mathrm{mg} / \mathrm{L} \\
\mathrm{mg} / \mathrm{L} \\
\mathrm{mg} / \mathrm{L} \\
\mathrm{mg} / \mathrm{L}\end{array}$ & $\begin{array}{l}.01 \\
.02 \\
.1 \\
.04 \\
.1 \\
\end{array}$ \\
\hline $\begin{array}{l}\text { Metals: } \\
\text { Aluminum } \\
\text { Arsenic } \\
\text { Barium } \\
\text { Beryllium } \\
\text { Boron } \\
\text { Cadmium } \\
\text { Calcium } \\
\text { Chromium } \\
\text { Cobalt } \\
\text { Copper } \\
\text { Iron } \\
\text { Lead } \\
\text { Magnesium } \\
\text { Manganese } \\
\text { Molybdenum } \\
\text { Nickel } \\
\text { Phosphorus } \\
\text { Potassium } \\
\text { Selenium } \\
\text { Silver } \\
\text { Sodium } \\
\text { Strontium } \\
\text { Vanadium } \\
\text { Zinc }\end{array}$ & $\begin{array}{l}\text { ND } \\
\text { ND } \\
\text { ND } .044 \\
\text { ND } \\
.001 \\
67 \\
\text { ND } \\
\text { ND } \\
\text { ND } \\
\text { ND } \\
.018 \\
4.8 \\
\text { ND } \\
\text { ND } \\
\text { ND } \\
\text { ND } \\
\text { ND } \\
\text { ND } \\
\text { ND } \\
7.9 \\
.42 \\
\text { ND } \\
.24\end{array}$ & $\begin{array}{l}\mathrm{mg} / \mathrm{L} \\
\mathrm{mg} / \mathrm{L} \\
\mathrm{mg} / \mathrm{L} \\
\mathrm{mg} / \mathrm{L} \\
\mathrm{mg} / \mathrm{L} \\
\mathrm{mg} / \mathrm{L} \\
\mathrm{mg} / \mathrm{L} \\
\mathrm{mg} / \mathrm{L} \\
\mathrm{mg} / \mathrm{L} \\
\mathrm{mg} / \mathrm{L} \\
\mathrm{mg} / \mathrm{L} \\
\mathrm{mg} / \mathrm{L} \\
\mathrm{mg} / \mathrm{L} \\
\mathrm{mg} / \mathrm{L} \\
\mathrm{mg} / \mathrm{L} \\
\mathrm{mg} / \mathrm{L} \\
\mathrm{mg} / \mathrm{L} \\
\mathrm{mg} / \mathrm{L} \\
\mathrm{mg} / \mathrm{L} \\
\mathrm{mg} / \mathrm{L} \\
\mathrm{mg} / \mathrm{L} \\
\mathrm{mg} / \mathrm{L} \\
\mathrm{mg} / \mathrm{L} \\
\mathrm{mg} / \mathrm{L}\end{array}$ & $\begin{array}{l}.2 \\
.005 \\
.01 \\
.002 \\
.6 \\
.001 \\
1 \\
.01 \\
.01 \\
.01 \\
.04 \\
.003 \\
1 \\
.01 \\
.05 \\
.02 \\
.3 \\
3 \\
.005 \\
.01 \\
1 \\
.003 \\
.02 \\
.02 \\
\end{array}$ \\
\hline
\end{tabular}

- The field conductivity value is not consistent with the measured TDS or individual analyte concentrations, and is probably erroneous. 

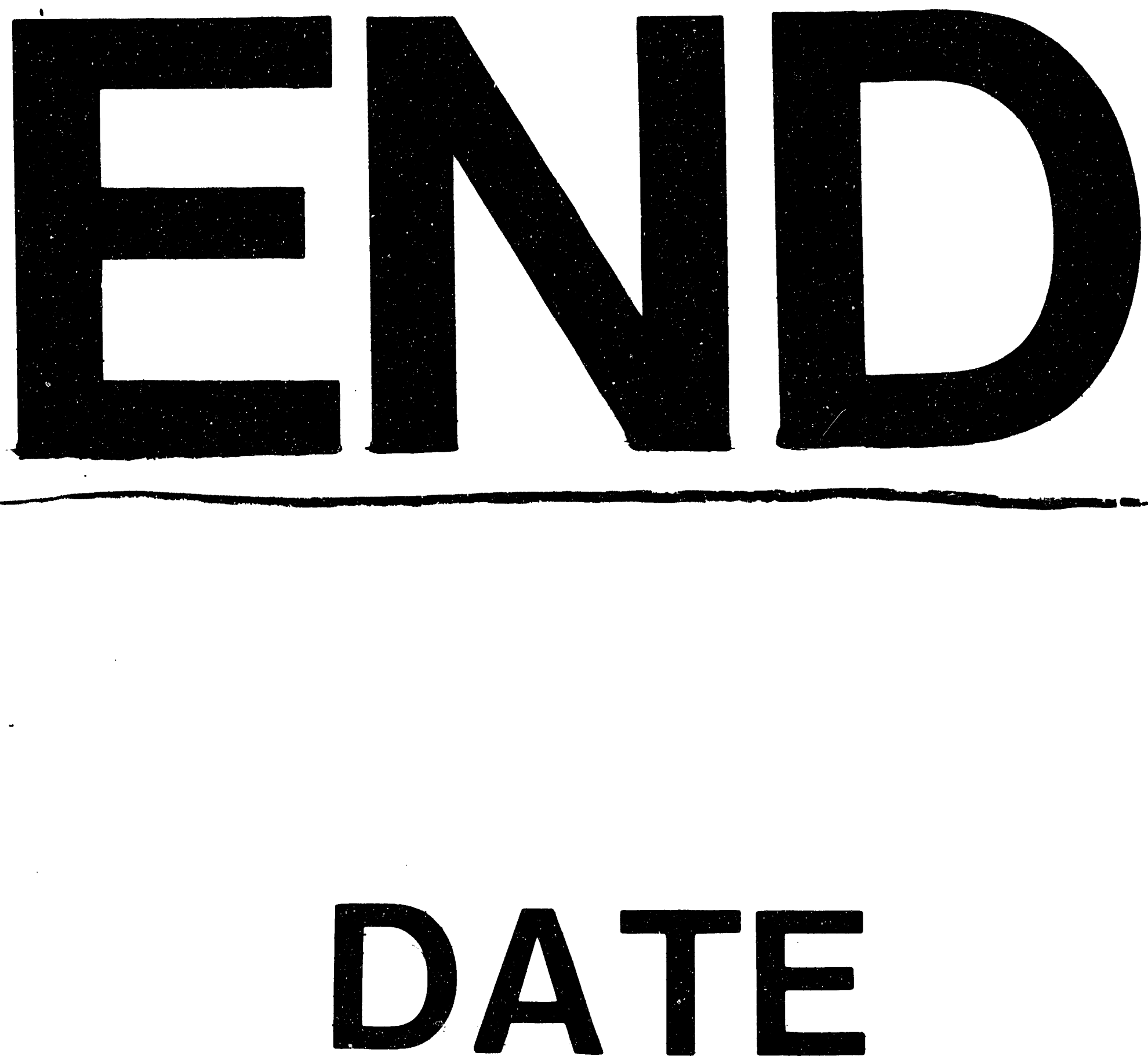

$\mid$
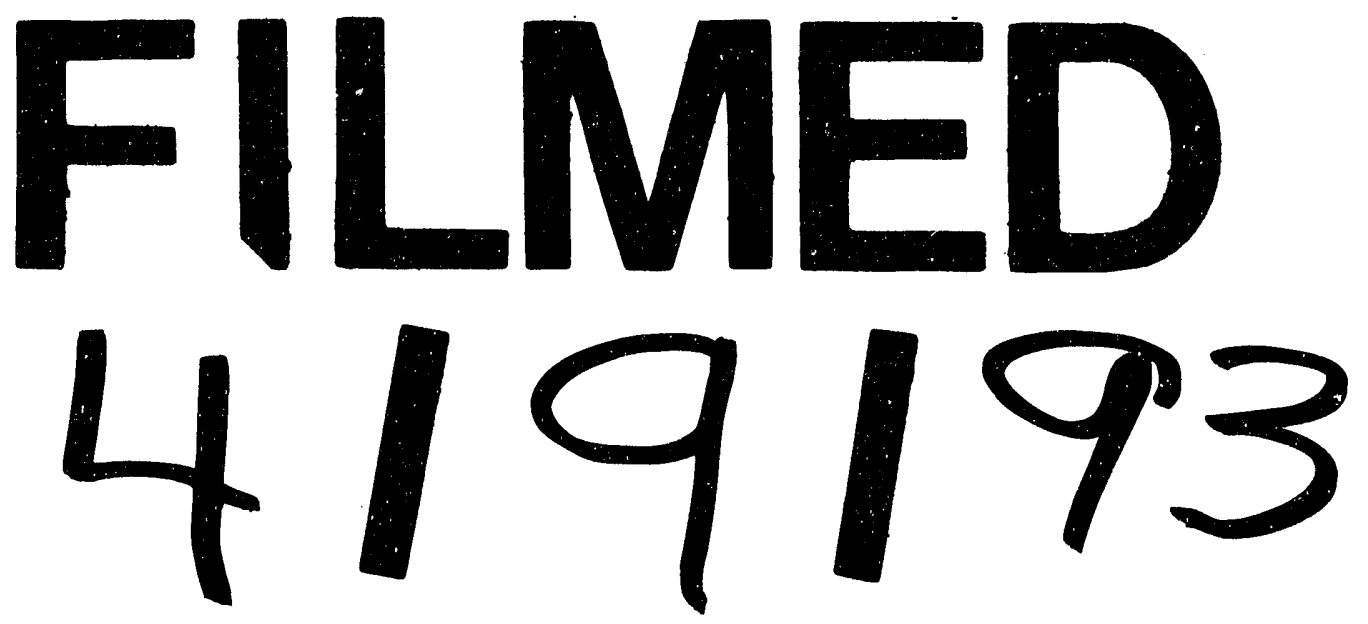